EWA KOZERSKA

Uniwersytet Opolski

TOMASZ SCHEFFLER

Uniwersytet Wrocławski

\title{
Retoryka ciągłości: o dziedzictwie prawnym II Rzeczypospolitej i rządów komunistycznych
}

Elity rodzącej się w 1989 r. tzw. III Rzeczypospolitej (w tym elity prawnicze) w sferze deklaracji głosiły odrzucenie dziedzictwa rządów komunistycznych oraz chęć przywrócenia niepodległej państwowości polskiej jako kontynuacji tradycji niepodległościowych rozwijanych w okresie międzywojennym. Wyrazisty przykład tego sposobu oficjalnej autoidentyfikacji stanowiły dwa epizody z początku i końca lat 90. XX w.: przejęcie w dniu 22 grudnia 1990 r. insygniów prezydenckich przez Lecha Wałęsę od Ryszarda Kaczorowskiego oraz uchwała Senatu Rzeczypospolitej Polskiej z 16 kwietnia 1998 r. o ciągłości prawnej między II a III Rzecząpospolitą Polską ${ }^{1}$. Oba fakty, pomimo odmiennej natury (w pierwszym wypadku mieliśmy przecież do czynienie z pewną sekwencją zdarzeń ze świata fizycznego mających pozór czynności konwencjonalnych, w drugim zaś $\mathrm{z}$ treścią aktu normatywnego będącą wynikiem czynności konwencjonalnej), były podobne zarówno w swej strukturze symbolicznej, jak i w swych irrelewantnych prawnie konsekwencjach. Tym samym dobrze oddawały dostrzegane przez nas ironiczne ${ }^{2}$ oblicze przemian zachodzących od 1989 r. W naszym przeświadczeniu jednym ze znamion współczesnego państwa polskiego jest bowiem częściowa pozorność jego zakorzenienia $\mathrm{w}$ dwóch odrębnych, w dużej części sprzecznych wewnętrznie, porządkach aksjologicznych i prawnych — jednym wywodzącym się z II Rzeczypospolitej i drugim ukształtowanym w Polsce Ludowej. W artykule przyjrzyjmy się zatem pokrótce obu wymienionym epizodom, starając się

1 M.P. z 1998 r. Nr 12, poz. 200.


maskowanie, ukrywanie (G. Reale, Historia filozofii starożytnej, t. 1. Od początków do Sokratesa, Lublin 1994, s. 375), oraz słowa Elp 
uwypuklić ich dwoisty charakter, a następnie prześledzimy wypowiedzi orzecznictwa i doktryny (zwłaszcza z okresu tzw. przełomu ustrojowego) w celu ustalenia, w jakim zakresie III Rzeczypospolita na poziomie mentalnościowym jest rzeczywiście spadkobiercą prawnym II Rzeczpospolitej, a w jakim — masy normatywnej i ideowej wygenerowanej przez rządy komunistyczne. Należy przy tym zastrzec, że naszym zamierzeniem nie jest szczegółowe określenie, jakie i w jakim zakresie akty normatywne z obu wymienionych okresów zostały przejęte przez III Rzeczypospolitą. Interesuje nas w tym miejscu wyłącznie to, czy oficjalna — nazwijmy ją tak — retoryka ciągłości między II a III Rzeczypospolitą ma jakiś znaczący wpływ na funkcjonujący w Polsce po 1989 r. system prawny. Innymi słowy, chcemy ustalić, jaka jest faktyczna treść retoryki ciągłości. Chcielibyśmy też zaznaczyć, że dzięki pracy (w tym żmudnej pracy archiwalnej) licznego grona historyków starszego i młodszego pokolenia (szczególnie tych związanych z Instytutem Pamięci Narodowej) zasadnicze elementy opisujące z punktu widzenia faktograficznego przebieg zmian zachodzących w schyłkowym PRL-u i początkach III Rzeczypospolitej są stosunkowo dobrze już znane ${ }^{3}$. Znacznie więcej wątpliwości budzą do

${ }^{3}$ Wśród licznych prac dotyczących tego zagadnienia wymieńmy tu przykładowo: T.G. Ash, Wiosna obywateli. Rewolucja 1989 widziana w Warszawie, Budapeszcie, Berlinie i Pradze, Londyn 1990; A. Małkiewicz, Wybory czerwcowe 1989, Warszawa 1994; Tajne dokumenty Biura Politycznego i Sekretariatu KC. Ostatni rok władzy 1988-1989, oprac. S. Perzkowski [Andrzej Paczkowski], Londyn 1994; J. Skórzyński, Ugoda i rewolucja. Władza i opozycja 1985-1989, Warszawa 1995; S. Kowalski, Narodziny III Rzeczypospolitej, Warszawa 1996; A. Paczkowski, Polska 1986-1989. Od kooptacji do negocjacji. Kilka uwag o wchodzeniu w proces zmiany systemowej, Warszawa 1997; P. Raina, Droga do „,Okragłego Stolu”. Zakulisowe rozmowy przygotowawcze, Warszawa 1999; Polska 1986-1989: koniec systemu. Materiaty międzynarodowej konferencji: Miedzeszyn, 21-23 października 1999, red. P. Machcewicz et al., t. 1-3, Warszawa 2002; S. Cenckiewicz, Oczami bezpieki. Szkice i materiaty z dziejów aparatu bezpieczeństwa PRL, Warszawa 2004; Partie i koalicje partyjne III Rzeczypospolitej, red. K.A. Paszkiewicz, Wrocław 2004; Okragły stót. Dokumenty i materiały, wyb. B. Brzostek et al., t. 1-5, Szczecin-Warszawa 2004; M. Pernal, J. Skórzyński, Gdy niemożliwe stało się możliwe. Kalendarium Solidarności 1980-1989, Warszawa 2005; A. Dudek, Ślady PeeReLu: ludzie, wydarzenia, mechanizmy, Kraków 2005; J. Skórzyński, Od Solidarności do wolności, Warszawa 2005; A. Dudek, Historia polityczna Polski 1989-2005, Kraków 2007; P. Codogni, Okragły Stól, czyli polski Rubikon, Warszawa 2009; S. Cenckiewicz, Dlugie ramię Moskwy. Wywiad wojskowy Polski Ludowej 1943-1991 (wprowadzenie do syntezy), Warszawa 2011; W. Roszkowski, Najnowsza historia Polski 1989-2011, Warszawa 2011; A. Dudek, Reglamentowana rewolucja. Rozkład dyktatury komunistycznej w Polsce 1988-1990, Kraków 2014. Pomocne są również (przy zachowaniu odpowiednich środków naukowej ostrożności) publikacje zawierające wspomnienia uczestników tamtych wydarzeń lub wywiady z nimi tudzież materiały zebrane przez dziennikarzy oraz nieopracowane naukowo zbiory dokumentów (np. P. Smoleński, Szermierze okrąglego stołu. Zwątpienia i nadzieje, Paryż-Warszawa 1989; Kto jest kim — Okragły stót. Solidarność, opozycja. Biogramy, wypowiedzi, red. W. Adamiecki et al., Warszawa 1989; Okragty stót, oprac. J. Barszczewski et al., cz. 1 i 2, Warszawa 1989; K. Leski, Coś, czyli rzecz o okragłym stole, Warszawa 1989; Polska, wybory '89, wyb. i układ R. Kałuża, Warszawa 1989; Z. Domarańczyk, 100 dni Mazowieckiego, Warszawa 1990; K. Dubiński, Magdalenka. Transakcja epoki. Notatki z poufnych spotkań Kiszczak-Wałęsa, Warszawa 1990; G. Konstanty, Mebel, Londyn 1990; Z. Mentzel, Pod kreska. Ostatnie kwartaty PRL, Warszawa-Londyn 1990; B. Geremek, J. Żakowski, Rok 1989. Bronisław Geremek odpowiada, Jacek Żakowski pyta,

Studia nad Autorytaryzmem i Totalitaryzmem 39, nr 2, 2017

(C) for this edition by CNS 
dziś motywy kierujące poszczególnymi aktorami ówczesnej sceny politycznej, jak też zakres wpływu czynników zewnętrznych na przebieg wydarzeń zachodzących w Polsce. Spory toczą się również - jak powszechnie wiadomo - w związku z próbami formułowania sądów wartościujących w tym zakresie. Rozwiązanie czy nawet próba rozwiązania tych kontrowersji nie znajduje się obecnie w kręgu celów naszej pracy. Dlatego też ograniczymy się w warstwie czysto historycznej do skrótowego odtworzenia dotychczasowych ustaleń odnoszących się do interesujących nas symbolicznych aktów wyrażających ciągłość między II i III Rzecząpospolitą.

Zanim przejdziemy do dalszych rozważań, warto w tym kontekście podkreślić jeszcze jedną rzecz: możliwość pomijania potencjalnego, trzeciego fundamentu obecnego porządku polityczno-prawnego, jaki mogłaby stanowić tradycja I Rzeczypospolitej. Wprawdzie na poziomie uroczystych formuł istniała jeszcze u zarania II RP tendencja do zaznaczania ciągłości przed- i porozbiorowej państwowości, jednak nie przełożyło się to nawet wówczas ani na kwestie przywrócenia przynajmniej części przedrozbiorowych rozwiązań ustrojowych (incydentalne zdarzenia, takie jak wypaczone odwołanie do pojęcia „Sejm”, czy to w II czy w III Rzeczypospolitej, tylko potwierdzają to zjawisko), ani na restytucję jakichkolwiek istotnych instytucji dawnego ładu prawnego. Co prawda można dosyć łatwo (czy nie nazbyt łatwo?) usprawiedliwić działania ówczesnych (i tym bardziej współczesnych) decydentów stwierdzeniem, że w wyniku rozbiorów doszło do przerwania „naturalnej ewolucji” rodzimych rozwiązań ustrojowych i prawnych, które stały się w związku z tym ,jako wzorzec ustrojowy nieprzydatne w warunkach rodzącej się nowej państwowości polskiej ze względu na swój anachronizm i nieprzystawalność do odmiennych warunków społeczno-politycznych"4, niemniej jednak nie zmienia to faktu, że już w 1918 r. nastąpiło wyraźne zerwanie instytucjonalnej oraz ideowej ciągłości między przed- i porozbiorową państwowością polską. Nie ma tu zresztą miejsca na polemikę z tym, przez bardzo wielu uznawanym za oczywisty (mimo że niepopartym żadnymi szerszymi badaniami i odwołującym się do ewolucjonistycznego paradygmatu), poglądem o niemożności sięgnięcia przy odbudowie państwowości polskiej do rodzimych tradycji. Przywołujemy go tylko po to, aby uwypuklić niezbyt często uświadamianą sobie rzecz: polskie prawo nie wywodzi się z prawa rodzimego; jest kontynuacją prawa pruskiego, niemieckiego, francuskiego, austriackiego czy rosyjskiego, ale nie polskiego; polski prawnik jest dziedzicem prawników niemieckich, francuskich, austriackich czy rosyjskich, a nie polskich. Skuteczne wykorzenienie, jakie przeprowadziły państwa zaborcze, zostało zaakceptowane

Warszawa 1990; M. Berezowski, Koniec epoki. Wywiady, Warszawa 1991; Rok 1989. Nowa Polska, odmieniona Europa, red. A. Kojder, Warszawa 1999; Okragły Stót, oprac. K. Dubiński, Warszawa 1999).

4 A. Kulig, Dwie prowizoryczne Konstytucje lutowe z 1919 r: polska i niemiecka, [w:] Ustroje historia i wspótczesność. Polska - Europa - Ameryka Lacińska. Ksiegga jubileuszowa dedykowana Profesorowi Jackowi Czajowskiemu, red. M. Grzybowski, G. Kuca, P. Mikuli, Kraków 2013, s. 201. 
przez polskie elity zarówno w 1918 r., jak i po 1989 r. Nie oceniamy tego, lecz jedynie wskazujemy na fakt wykorzenienia (i wydziedziczenia) oraz dobrowolnej zgody spadkobierców na konsekwencje owego procesu, wśród których znajduje się niemożność sięgnięcia do rozwiązań występujących w przedrozbiorowej Rzeczypospolitej jako rezerwuaru wzorców oraz źródła historycznie legitymizującego władzę i prawo współczesnego państwa polskiego ${ }^{5}$. Pozostaje nam zatem skupienie się na przywołanej wyżej parze tradycji wywodzących się z II Rzeczypospolitej i Polski Ludowej.

\section{$* * *$}

Pierwsze z wymienionych symbolicznych zdarzeń z lat 90. XX w. (przekazanie insygniów) było związane ze zmianą osoby sprawującej urząd Prezydenta Rzeczypospolitej Polskiej, co zaś było efektem tzw. wojny na górze i wynikającej z niej przebudowy polskiej sceny politycznej. Wyraźne symptomy owych przemian ujawniły się w styczniu 1990 r. i wraz z upływem kolejnych miesięcy doprowadziły do wykrystalizowania się $\mathrm{w}$ łonie formacji postsolidarnościowej dwóch zwalczających się obozów: jednego skupionego wokół rządu Tadeusza Mazowieckiego i „Gazety Wyborczej” kierowanej przez Adama Michnika, drugiego - wokół aspirującego do roli prezydenta RP Lecha Wałęsy, wspieranego w tym czasie przez większość lokalnych struktur komitetów obywatelskich oraz związek zawodowy Solidarność 6 . Ostatecznie, po licznych utarczkach (czasem na żenującym wręcz poziomie ${ }^{7}$ ) doszło za zgodą gen. Wojciecha Jaruzelskiego

${ }^{5} \mathrm{Z}$ tego też powodu nie mogła w Polsce rozwinąć się (na podobieństwo niemieckiej lub angielskiej) szkoła historyczna w prawoznawstwie i to mimo że w części były to rozwiązania zakorzenione w systemach normatywnych pozapolskich (np. w odniesieniu do praw miejskich czy lokacji wsi). Odrębne zagadnienie, natury już raczej psychologicznej niż prawnej, stanowi łatwość, z jaką polskie tradycje prawne są apriorycznie uznawane przez XX-wieczne i współczesne środowiska prawnicze wyłącznie za historyczną ciekawostkę.

6 Jak wiemy, podział ten, pomimo licznych mutacji organizacyjnych oraz czasem bardzo znaczących fluktuacji personalnych (przejście samego Lecha Wałęsy do zwalczanego przez siebie wcześniej obozu), przetrwał do dziś i ciągle determinuje główną oś sporów politycznych (spór PO-PiS). Jako podstawowe formacje polityczne kreujące u zarania „wojnę na górze” powstały: prowałęsowskie Porozumienie Centrum (12 maja 1990 r.) i promazowiecki Sojusz na Rzecz Demokracji (10 czerwca 1990 r.), przekształcony wkrótce w Ruch Obywatelski Akcja Demokratyczna (16 lipca 1990 r.), oraz Forum Prawicy Demokratycznej (27 czerwca 1990 r.). Warto zauważyć, że wbrew tendencjom do odczytywania tego podziału w kategoriach Giedroyciowych dwóch trumien (Dmowskiego i Piłsudskiego), bardziej przypomina on mentalne pęknięcie społeczeństwa polskiego oddane w Niemcewiczowskim Powrocie posła.

7 Paradygmatyczną egzemplifikacją tego stanu polemik stały się słowa Adama Michnika: „Jeżeli ja jestem lewicą laicką i kryptokomunistą, to wy, szanowni moi antagoniści, jesteście po prostu świ[...]” (cyt. za: W. Roszkowski, op. cit., s. 37). Widzimy tu, jak etykiety „polityczne” zostają zastąpione odczłowieczającym epitetem. Jak pamiętamy, wkrótce ten sposób argumentacji (np. słynny „zoologiczny antykomunizm”) stanie się podstawowym narzędziem walki politycznej. 
(piastującego też wówczas urząd Prezydenta RP) do uzgodnienia między stronami stanowiska zakładającego konieczność przeprowadzenia zmian legislacyjnych umożliwiających rozpisanie wyborów prezydenckich ${ }^{8}$. Pierwsza tura wyborów, która odbyła się 25 listopada 1990 r., przyniosła zaskakujące wyniki: wprawdzie najlepszy rezultat - zgodnie z przewidywaniami - uzyskał Lech Wałęsa (39,96\% głosów), to jednak kolejny wysoki wynik przypadł „kandydatowi znikąd" - jak mówiono - Stanisławowi Tymińskiemu (23,1\% głosów), dopiero na trzecim miejscu znalazł się faworyzowany przez większość przedstawicieli elit intelektualnych Tadeusz Mazowiecki (18,08\% głosów) ${ }^{9}$. Szok wśród „wykształconych", wywołany ujawnieniem się sporego potencjału antyestablishmentowego istniejącego w społeczeństwie, doprowadził do taktycznego sojuszu ,pookrągłostołowych" obozów (a nawet antymagdalenkowej Konfederacji Polski Niepodległej) oraz radykalnego ataku wszystkich znaczących mass mediów na osobę Tymińskiego (łącznie z jego życiem rodzinnym). W konsekwencji w drugiej turze wyborów (9 grudnia 1990 r.) zdecydowanie zwyciężył Wałęsa, uzyskując poparcie na poziomie $74,25 \%$ ważnych głosów ${ }^{10}$.

Zwycięstwo wyborcze i rychła perspektywa objęcia urzędu Prezydenta Rzeczpospolitej Polskiej przez legendę Sierpnia 1980 r. Lecha Wałęsę przez wiele osób i środowisk uznane zostało za moment przełomowy. Przyjmowano bowiem, że odsuwając w ten sposób pokojowo od władzy ostatniego, wysokiego reprezentanta komunistycznego reżimu Wojciecha Jaruzelskiego, niejako symbolicznie zerwie się z PRL-owską przeszłością i otworzy nowy, niepodległy rozdział historii Polski. W tym duchu właśnie zaprezentowany został dekret ostatniego prezydenta Rzeczypospolitej (na Uchodźstwie) Ryszarda Kaczorowskiego ${ }^{11}$ o zakończeniu

8 Ich wynikiem była Ustawa z dnia 27 września 1990 r. o wyborze Prezydenta Rzeczypospolitej Polskiej (Dz.U. z 1990 r. Nr 67, poz. 398; Dz.U. z 1990 r. Nr 79, poz. 465).

9 Zob. szerzej Obwieszczenie Państwowej Komisji Wyborczej z dnia 26 listopada 1990 r. o wynikach głosowania i wyniku wyborów Prezydenta Rzeczypospolitej Polskiej, zarządzonych na dzień 25 listopada 1990 r. (Dz.U. z 1990 r. Nr 83, poz. 483).

${ }^{10} \mathrm{Na}$ Tymińskiego oddano odpowiednio 25,75\% ważnych głosów. Zob. szerzej Obwieszczenie Państwowej Komisji Wyborczej z dnia 10 grudnia 1990 r. o wynikach ponownego głosowania i wyniku wyborów Prezydenta Rzeczypospolitej Polskiej (Dz.U. z 1990 r. Nr 85, poz. 499). W kwestii przebiegu wydarzeń z 1990 r. zob. szerzej W. Roszkowski, op. cit., s. 32-39, 45-47; A. Dudek, Reglamentowana ..., s. 423-432. Ciekawymi zjawiskami, po raz pierwszy wówczas odnotowanymi, były z jednej strony znaczący spadek frekwencji pomiędzy pierwszą i drugą turą wyborów (w liczbach bezwzględnych uczestnictwo spadło o 2396206 osób uprawnionych do głosowania) i jednoczesny wzrost (w stosunku do pierwszej tury) o prawie 100 tys. głosów nieważnych. Zauważmy też, że to, co wywołało popłoch elit, czyli możność zmobilizowania się przeciwników systemu na poziomie nawet około jednej czwartej aktywnych uczestników wyborów, w rzeczywistości stanowił stały element pejzażu politycznego wielu krajów demokratycznych, w których, w zależności od okoliczności wewnątrzpolitycznych, rozproszone poparcie dla takich ruchów oscyluje w granicach $5-25 \%$.

11 Gwoli ścisłości należy przypomnieć, że jako prezydent Wolnej Polski na Wychodźstwie działał jeszcze Juliusz Nowina-Sokolnicki. Nie miejsce tu na rozstrzygnięcie sporu co do jego roszczeń (bezpodstawnych naszym zdaniem) do roli legalnego kontynuatora władztwa II Rzeczypospo- 
działalności oraz o rozwiązaniu Rządu Rzeczypospolitej na Uchodźstwie. Przypomnijmy tu dwa podstawowe zapisy owego aktu, które dobrze odzwierciedlają owe nastawienie:

Art. 1. Naród w wyborach powszechnych wybrał Lecha Wałęsę Prezydentem Rzeczypospolitej, który obejmie urząd Prezydenta Rzeczypospolitej w dniu 22 grudnia 1990 roku. Art. 2. Misja Prezydenta Rzeczypospolitej na Uchodźstwie została wypełniona i zakończona i w dniu 22 grudnia przekaże Prezydentowi Lechowi Wałęsie insygnia prezydenckie jako symbol II Rzeczypospolitej ${ }^{12}$.

Uzasadniając w orędziu z 21 grudnia 1990 r. $^{13}$ „oddanie” 14 urzędu, prezydent Kaczorowski wzmocnił dodatkowo to przekonanie, gdyż powołał się na deklarację prezydenta Władysława Raczkiewicza z 29 czerwca 1945 r. (powtarzaną następnie przez kolejnych prezydentów, łącznie z samym Kaczorowskim), w której zostało złożone zapewnienie przekazania urzędu następcy wyłonionemu przez naród „w wolnych i nieskrępowanych wyborach”. Za takie zaś uznano wybory z 9 grudnia 1990 r. i ich konsekwencję, czyli elekcję przez naród „zdecydowaną większością głosów [...] Lecha Wałęsy, przywódcę legendarnej już »Solidarności«" na urząd Prezydenta RP. Dlatego też, jak podkreślił prezydent Kaczorowski:

litej. Jako ciekawostkę warto jednak odnotować, że Juliusz Nowina-Sokolnicki przyznawał różnego rodzaju tytuły i odznaczenia; jednym z nich obdarzył też Lecha Wałęsę, który w liście z podziękowaniami określił Nowinę-Sokolnickiego mianem Prezydenta. Zob. http://sokolnicki.republika.pl/ $\mathrm{html} /$ wlesa_podziekowanie.html (dostęp: 1.04.2017).

12 Dekret Prezydenta Rzeczypospolitej z dnia 20 grudnia 1990 r. o zakończeniu działalności i rozwiązaniu Rządu Rzeczypospolitej na Uchodźstwie (Dz.U. z 1990 r. Nr 5, poz. 55). Na ów krótki akt składały się jeszcze trzy zapisy o następującej treści: „Art. 3. Wobec wypełnienia misji prezydenckiej odwołuję Prezesa Rady Ministrów z urzędu i rozwiązuję Rząd. Art. 4. Zostaje powołana Komisja Likwidacyjna, która doprowadzi do zakończenia działalności wszystkich instytucji rządowych na obczyźnie. Art. 5. Dekret niniejszy wchodzi w życie z dniem podpisania". Zwracamy uwagę na specyficzny język dekretu mieszający sformułowania nienormatywne (opisowe - art. 1) z tekstem normatywnym (art. 3-5). Szczególny konglomerat obu konwencji stanowi art. 2, który z jednej strony stanowił swoisty opis stanu faktycznego, z drugiej zaś nakładał na Prezydenta Rzeczypospolitej na Uchodźstwie bezsankcyjny obowiązek konkretnego jednorazowego zachowania.

13 Orędzie Prezydenta Rzeczypospolitej Ryszarda Kaczorowskiego wydane w Londynie 21 grudnia 1990 r. (Dz.U. z 1990 r. Nr 5, dział nieurzędowy, s. 126-127, dalej: orędzie).

${ }^{14}$ Warto zaznaczyć, Konstytucja kwietniowa nie przewidywała instytucji „oddania” urzędu Prezydenta. Posłużenie się słowem „oddanie” można uznać za dozwolone w orędziu, czyli w tekście nienormatywnym, niemniej jednak warto odnotować, że także w cytowanym dekrecie z 22 grudnia 1990 r. nie ma odwołania do trybu przekazania urzędu Prezydenta przewidzianego w Konstytucji z 1935 r. Co więcej, w art. 2. dekretu przewidywało się wyłącznie swoistą abdykację Prezydenta RP na Uchodźstwie oraz przekazanie Lechowi Wałęsie nie urzędu, lecz wyłącznie insygniów prezydenckich ,jako symbolu” odrodzonego w 1918 r. państwa polskiego. Było to bardzo specyficzne ujęcie zagadnienia transferu legalnej władzy, które w tekście pozaprawnym (czyli w orędziu) zostało dodatkowo zmodyfikowane. Zresztą, jak zwrócimy na to uwagę w dalszej części tekstu, nawet ten ułomny mechanizm mający sugerować zachowanie legalnej ciągłości między II i III Rzecząpospolitą został w ostatecznym rozrachunku zarzucony przez władze krajowe. 
Oddając jutro Lechowi Wałęsie na Zamku Królewskim w Warszawie urząd Prezydenta Rzeczypospolitej i związane z nim insygnia, oddam mu w opiekę całą, niepodległą, wolną, demokratyczną i sprawiedliwą Polskę, o którą walczyli żołnierze Września 1939 r., Polskich Sił Zbrojnych na Zachodzie i bohaterskiej Armii Krajowej ${ }^{15}$.

Warto tu zwrócić uwagę, że z treści cytowanego orędzia wynikałoby coś więcej niż z zapisów samego dekretu o zakończeniu działalności, a mianowicie, że dla Prezydenta Kaczorowskiego (i zapewne też jego środowiska) akt przekazania insygniów miał łączyć się już nie tylko symbolicznie, ale również prawnie (choć w trybie konstytucyjnie wątpliwym) z przekazaniem urzędu Prezydenta Rzeczypospolitej. Całe zdarzenie, które miało mieć miejsce dzień później (tj. 22 grudnia 1990 r.), było zatem pomyślane z punktu widzenia spadkobierców prawnych II Rzeczypospolitej jako akt przelania władzy państwowej i ustanowienia ciągłości między II i III Rzeczpospolitą ${ }^{16}$. Co ważne, również — przynajmniej niektórzy - luminarze krajowi chcieli w tych kategoriach postrzegać akt przekazania insygniów. Z tego powodu Marszałek Senatu, jedynego jeszcze wówczas demokratycznie ukonstytuowanego organu państwa, prof. Andrzej Stelmachowski (w porozumieniu ,z misją wydelegowaną" przez prezydenta Kaczorowskiego ${ }^{17}$ ) przedstawił projekt protokołu przebiegu ceremonii, który w przypadku ziszczenia się mógłby być podstawą interpretacji jej jako czynności konwencjonalnej. Organizacja uroczystości miała podkreślać równorzędność i jednocześnie następstwo osób sprawujących urząd Prezydenta. Zostało to zaznaczone kilkoma dyplomatycznymi gestami (oprawa przylotu i przyjęcia prezydenta Kaczorowskiego na lotnisku w Warszawie ${ }^{18}$ czy analogiczność ceremoniału w odniesieniu do obu prezydentów na Zamku Królewskim) oraz przyznaniem roli swoistego kapłana pośredniczącego „między dawnymi i młodszymi laty” depozytariuszowi dawnej tradycji polskiej w młodszej, demokratycznej odsłonie, czyli wspomnianemu Marszałkowi Senatu RP. Najważniejszym jednak z symbolicznego i prawnego punktu widzenia momentem ceremoniału miało stać się podpisanie

15 Orędzie, s. 126.

${ }^{16} \mathrm{Na}$ taką intencję wskazują również inne fragmenty orędzia, takie jak np.: „Życzę naszemu dostojnemu następcy sił [...] w tym przełomowym okresie historii naszego narodu”; „Oddam Prezydentowi Lechowi Wałęsie zwierzchnictwo nad emigracją niepodległościową [...]”; czy też najbardziej dobitny: „Przekazując urząd Prezydenta Rzeczypospolitej z Londynu do Warszawy [...]”, s. 126-127).

17 Zob. szerzej datowane na 18 grudnia 1990 r. Zaproszenie do Warszawy Prezydenta Rzeczypospolitej Ryszarda Kaczorowskiego dla przekazania insygniów i urzędu prezydenckiego na Zamku Królewskim w Warszawie w dniu 22 grudnia 1990 r., skierowane przez Marszałka Senatu RP Andrzeja Stelmachowskiego „W uzgodnieniu z Prezydentem-Elektem Lechem Wałęsą” do Prezydenta Ryszarda Kaczorowskiego (Dz.U. z 1990 r. Nr 5, dział nieurzędowy, s. 127-128).

18 Zob. szerzej komunikat Kancelarii Cywilnej Prezydenta Rzeczypospolitej o przejeździe Prezydenta Rzeczypospolitej Ryszarda Kaczorows[kiego — dop. E.K., T.S.] z Londynu do Kraju oraz powitaniu w Warszawie w dniu 22.XII.[1990] r. (Dz.U. z 1990 r. Nr 5, dział nieurzędowy, s. 132-133). 
protokołu przekazania insygniów ${ }^{19}$ przez obu prezydentów ${ }^{20}$, gdyż zdarzenie to miało oddawać fakt sukcesji władzy. Jak wiemy, właśnie ten kulminacyjny punkt uroczystości został w ostatniej chwili zakwestionowany przez Lecha Wałęsę. Do wzajemnego podpisania protokołu nie doszło, a dokument potwierdzający przy-

19 Gwoli ścisłości przypomnijmy, co składało się na „insygnia”, odwołując się do Komunikatu Kancelarii Cywilnej Prezydenta Rzeczypospolitej o przewiezieniu z Londynu insygniów prezydenckich na Zamek Królewski w Warszawie (Dz.U. z 1990 r. Nr 5, dział nieurzędowy, s. 131-132): „Kancelaria Cywilna podaje do wiadomości, że następujące insygnia suwerenności Państwa i urzędu Prezydenta Rzeczypospolitej pozostające od 1939 roku poza granicami Kraju, początkowo we Francji, a od 1940 roku w Anglii w Londynie w siedzibie Prezydenta Rzeczypospolitej zostały w dniu 22 grudnia 1990 roku przewiezione do Warszawy i przekazane Dyrektorowi Zamku Królewskiego prof. Aleksandrowi Gieysztorowi. Przewiezienie nastąpiło w związku z przygotowywanym aktem przekazania takowych przez Prezydenta Rzeczypospolitej na Uchodźstwie Ryszarda Kaczorowskiego nowo obranemu Prezydentowi Rzeczypospolitej Lechowi Wałęsie:

- Oryginalna chorągiew Rzeczypospolitej, którą Prezydent Rzeczypospolitej prof. Ignacy Mościcki, opuszczając Zamek w Warszawie w czasie wojny w 1939 roku, zabrał, a następnie po swej rezygnacji przekazał swemu następcy Prezydentowi Rzeczypospolitej Władysławowi Raczkiewiczowi we Francji.

— Trzy metalowe pieczęcie $z$ nadpisem »Prezydent Rzeczypospolitej« wykonane przez Mennicę Państwową w Warszawie będące przed wojną w normalnym użyciu przez Kancelarię Cywilną Prezydenta Rzeczypospolitej: jedna do tuszu, druga do laku i trzecia do wytłaczania w papierze.

— Jednocześnie został przekazany oryginał Ustawy Konstytucyjnej z 1935 roku pisany ręcznie na pergaminie z wyciskiem w laku pieczęci państwowej z nadpisem: »Rzeczpospolita«. Pieczęć ta w czasie wojny zaginęła.

— Trzy pieczęcie metalowe do tuszu różnej wielkości w nadpisem »Kancelaria Senatu«. Pieczęcie te zostały wywiezione w czasie wojny w 1939 roku przez ówczesnego sekretarza Marszałka Senatu.

- Pieczęć metalowa do wytłaczania w papierze Kapituły Orderu Orła Białego wykonana i używana przed wybuchem wojny 1939 roku.

- Pieczęć metalowa do wytłaczania w papierze Kapituły Orderu Odrodzenia Polski /Polonia Restituta/ używana przed wybuchem wojny w 1939 roku.

— Komplet Orderu Orła Białego w pudełku — Gwiazda, Krzyż oraz Wstęga. Egzemplarz używany przez wszystkich kolejnych Prezydentów Rzeczypospolitej przebywających poza granicami Kraju.

— Komplet I klasy Orderu Odrodzenia Polski w pudełku: Gwiazda, Wielki Krzyż i Wstęga. Egzemplarz używany przez wszystkich kolejnych Prezydentów Rzeczypospolitej od 1939 roku przebywających poza Krajem".

${ }^{20}$ Program uroczystości przekazania insygniów władzy prezydenckiej na Zamku Królewskim w Warszawie dnia 22 grudnia 1990 r. (Dz.U. z 1990 r. Nr 5, dział nieurzędowy, s. 129-131). Zgodnie z ustaleniami kulminacja tego swoistego rytuału miała wyglądać następująco: „Marszałek Senatu RP Pan A. Stelmachowski zaprasza Prezydenta RP Pana L. Wałęsę i Pana Prezydenta R. Kaczorowskiego do zajęcia miejsca za stołem w celu podpisania protokołu przekazania insygniów władzy prezydenckiej. Po prawej stronie Pana Marszałka Senatu RP miejsce zajmuje Pan Prezydent RP, po lewej Pan Prezydent R. Kaczorowski. Pod protokołem podpisy składają w kolejności Pan Prezydent R. Kaczorowski, Prezydent RP Pan L. Wałęsa i Marszałek Senatu RP Pan A. Stelmachowski. Po złożeniu podpisów Pan Prezydent RP, Pan Prezydent R. Kaczorowski i Pan Marszałek Senatu udają się do stołu, gdzie są wyłożone insygnia władzy prezydenckiej. Krótkie zatrzymanie się przed stołem, gdzie są wyłożone insygnia władzy prezydenckiej. Wykonanie hymnu narodowego przez chór”.

Studia nad Autorytaryzmem i Totalitaryzmem 39, nr 2, 2017

(C) for this edition by CNS 
jęcie insygniów sygnował jedynie Marszałek Senatu RP w obecności obu prezydentów. W ten sposób Andrzej Stelmachowski z rangi celebransa spadł do roli notariusza potwierdzającego przejęcie nobliwych, acz już przecież muzealnych pamiątek $^{21}$.

Można to odstępstwo od wcześniej uzgodnionej procedury uznać za niewiele znaczące zdarzenie ${ }^{22}$, niemniej jednak zniweczyło ono wszelką możliwość nałożenia na ceremonię kliszy zdarzenia konwencjonalnego, dzięki której można byłoby założyć, iż doszło do transferu władzy z Ryszarda Kaczorowskiego (urzędu Prezydenta Rzeczypospolitej Polskiej na Uchodźstwie), reprezentującego porządek prawny i państwowy II Rzeczpospolitej, na Lecha Wałęsę (urząd Prezydenta Rzeczypospolitej Polskiej) reprezentującego władze ukształtowane na ziemiach między Odrą i Bugiem. W tym wypadku za retoryką ciągłości, która najbardziej dobitnie ujawniła się w przemówieniu Marszałka Senatu $\mathrm{RP}^{23}$, ukrywało się faktyczne zakorzenienie nowej struktury władczej w rozwiązaniach ustrojowo-prawnych ancien régime. Innymi słowy, zdarzenie, które miało dawać usprawiedliwienie tezie o rzekomej ciągłości państwowej między II i III Rzeczpospolitą, dzięki drobnej zmianie w sferze symbolicznej potwierdziło, że nowe władze, pomimo odmiennych werbalnych komunikatów, poszukują usprawiedliwienia i zalegalizowania swojej władzy, w masie normatywnej wygenerowanej przez reżim komunistyczny.

Podobny wydźwięk, jak za chwilę powiemy, miało drugie z wymienionych wcześniej symbolicznych zdarzeń z lat 90 . XX w., czyli przyjęcie przez Senat RP uchwały o ciągłości prawnej między II a III Rzeczypospolitą Polską. W 2 pkt tego aktu Senat zadeklarował uznanie wyrażającej się „w ich suwerennym i niepodległym bycie" ciągłości prawnej II i III Rzeczypospolitej Polskiej oraz stwierdził jednocześnie, że

21 Taki też los spotkał insygnia prezydenckie: stały się częścią zasobów muzealnych. Warto tu podkreślić, że sam fakt stania się insygniów eksponatami muzealnymi nie musi pociągać za sobą deprecjonowania ich żywego znaczenia prawnego. Wystarczy zobaczyć, jak państwo brytyjskie znakomicie potrafi wykorzystać dawne, „umuzealnione” rzeczy uosabiające panowanie monarsze do umocnienia współczesnego ustroju poprzez pokazanie ciągłości i legalności władzy. Na tym polega podstawowa różnica w podejściu do symbolicznych artefaktów: w tradycji brytyjskiej symbole te pozostają żywe, w tradycji polskiej są już tylko martwą pamiątką po dawnym świecie. To sentymentalne podejście dobrze oddają również przemówienia wygłoszone podczas ceremonii przekazania insygniów. Zob. szerzej Dz.U. z 1990 r. Nr 5, dział nieurzędowy, s. 112-114.

22 Jeżeli uznamy, że Ernst Cassirer ma rację, że człowiek to animal symbolicum, to różnego rodzaju odstępstwa od ustalonych zachowań w danym kontekście kulturowym nie są tylko przypadkiem pozbawionym znaczenia, lecz wywołują w świadomości ludzkiej, czasem nierozeznane w pierwszej chwili, ważne dla egzystencji reakcje. W kwestii Cassirerowskich form symbolicznych i koncepcji kultury jako kosmosu form symbolicznych zob. szerzej J. Sójka, O koncepcji form symbolicznych Ernsta Cassirera, Warszawa 1988.

${ }^{23}$ Zob. Dz.U. z 1990 r. Nr 5, dział nieurzędowy, s. 112. 
narzucona w dniu 22 lipca 1952 r. konstytucja niesuwerennego państwa nie podważyła legalnie mocy prawnej Ustawy Konstytucyjnej Rzeczypospolitej Polskiej z dnia 23 kwietnia 1935 r. oraz opartego na niej porządku prawnego.

\section{Następnie w 3 pkt uchwały Senat wyraził}

wdzięczność organom państwa polskiego na uchodźstwie, które działając na podstawie Konstytucji Kwietniowej z 1935 r. umożliwiły zachowanie ciągłości prawnej między II i III Rzecząpospolitą Polską, a także tym wszystkim, którzy swą walką w kraju i na obczyźnie przyczynili się do przywrócenia niepodległości i suwerenności Rzeczypospolitej Polskiej.

Gdyby tylko do tych dwóch fragmentów ograniczała się rzeczona uchwała, to sprawa podejścia senatorów do „ciągłości” wydawałaby się stosunkowo prosta, a potencjalne spory interpretacyjne lub ideowe skupiałyby się zapewne na kwestii legalności wprowadzenia Konstytucji kwietniowej i co za tym idzie na trafności stanowiska Senatu w zakresie odwołania się do ustawy zasadniczej z 1935 r.

Wystarczy jednak przecież chwilę się zastanowić, aby powziąć pewne wątpliwości co do faktycznego znaczenia przywołanych sformułowań. Senatorowie w rzeczywistości nie stwierdzili bowiem w nich, że „narzucona konstytucja” z 1952 r. nie miała przymiotu regulacji prawnej wiążącej dla organów państwa i obywateli, a jedynie, że „nie podważyła legalnie mocy prawnej” Konstytucji kwietniowej. Co warte przypomnienia, faktycznie ani Konstytucja PRL ${ }^{24}$, ani ustawa konstytucyjną ją wprowadzająca ${ }^{25}$ nie derogowały Konstytucji kwietniowej; uczynił to bowiem Manifest Polskiego Komitetu Wyzwolenia Narodowego, a zatem nawet nie jakiś akt przyjmujący przynajmniej pozory aktu prawnego, tylko akt otwarcie polityczny określający Konstytucję z 1935 r. mianem „bezprawnej” i ,faszystowskiej”"26. Tym samym uchwała Senatu mogła być odczytana w tym zakresie (wbrew pierwszemu wrażeniu) nie tyle jako wezwanie do przywrócenia porządku prawnego zbudowanego na systemie normatywnym II Rzeczypospolitej, ile raczej jako potwierdzenie pewnego stanu rzeczy utrwalonego w okresie komunistycznym. Tym bardziej że Konstytucja PRL (i wspomniana ustawa konstytucyjna zawierająca regulacje wprowadzające) uchylały tylko tzw.

24 Konstytucja Polskiej Rzeczypospolitej Ludowej uchwalona przez Sejm Ustawodawczy w dniu 22 lipca 1952 r. (Dz.U. z 1952 r. Nr 33, poz. 232 z późn. zm.).

25 Ustawa Konstytucyjna z dnia 22 lipca 1952 r. - Przepisy wprowadzające Konstytucję Polskiej Rzeczypospolitej Ludowej (Dz.U. z 1952 r. Nr 33, poz. 233).

${ }^{26}$ Zob. szerzej M. Kallas, A. Lityński, Historia ustroju i prawa Polski Ludowej, Warszawa 2003, s. 42-43. Osobnym zagadnieniem godnym skrupulatnych badań jest stosunek przedstawicieli prawniczych środowisk naukowych, szczególnie tzw. konstytucjonalistów, do kwestii wpływu Manifestu PKWN na porządek prawny funkcjonujący w Polsce, osobliwie zaś na obowiązywanie Konstytucji kwietniowej. Możliwe, że udałoby się zweryfikować schmittowską tezę Franciszka Ryszki, postawioną w kontekście sporów o legalność wprowadzenia stanu wojennego w dniu 13 grudnia 1981 r., że istotną rolę w życiu publicznym odgrywa jedynie decyzja polityczna; po jej podjęciu, niezależnie od treści, pojawią się zawsze uczeni juryści, aby ją uzasadnić. Por. T. Scheffler, Prawne aspekty wprowadzenia stanu wojennego w Polsce w dniu 13 grudnia 1981 r., [w:] Idee jako źródto instytucji politycznych i prawnych, red. L. Dubel, Lublin 2003, s. 383-403. 
Małą Konstytucję z 1947 r. ${ }^{27}$ oraz pośrednio (w zamyśle twórców tego aktu) tzw. Konstytucję marcową z $1921 \mathrm{r}^{28}$ w zakresie, w jakim Manifest PKWN i pozostałe decyzje nowego reżimu deklarowały jej rzekome przestrzeganie. Czy więc możemy zakładać, że senatorzy, procedując nad uchwałą, nie znali tych wszystkich okoliczności? Czy też raczej powinniśmy przyjąć, że za formułą o niepodważaniu przez Konstytucję PRL-owską „legalnej mocy” Konstytucji z 1935 r. znajduje się zamaskowane znaczenie? Wrażenie istnienia ukrytego, innego niż uzyskanego prima facie sensu, pogłębiają jeszcze dwa dodatkowe punkty zawarte w rzeczonej uchwale. W pierwszym (1 pkt uchwały) z nich Senat uznał

państwo utworzone w wyniku II wojny światowej na ziemiach polskich i funkcjonujące w latach 1944-1989 za niedemokratyczne państwo o totalitarnym systemie władzy, będące elementem światowego systemu komunistycznego, pozbawione suwerenności i nie realizujące zasady zwierzchnictwa Narodu.

W drugim (w systematyce uchwały jest to 4 pkt) Senat stwierdził,

że akty normatywne stanowione przez niesuwerennego prawodawcę w latach 1944-1989 pozbawione są mocy prawnej, jeśli godziły w suwerenny byt państwa polskiego lub są sprzeczne z zasadami prawa uznawanymi przez narody cywilizowane, znajdującymi swój wyraz w Powszechnej Deklaracji Praw Człowieka. Dotyczy to w szczególności aktów normatywnych naruszających podstawowe prawa i wolności obywatelskie. Zaliczyć do nich należy akty pozbawiające obywatelstwa polskiego, czyniące z prawa karnego narzędzie prześladowania ludzi walczących o niepodległość lub różniących się przekonaniami światopoglądowymi, a także akty, na których podstawie dokonano niesprawiedliwego pozbawienia własności.

W tych dwóch cytowanych fragmentach możemy już wyraźnie zauważyć podstawowy problem będący przedmiotem naszego artykułu: czy deklaracja o istnieniu ciągłości między II i III Rzecząpospolitą jest wyrazem pewnej rzeczywistości normatywnej, czy też stanowi tylko swoistą woalkę, za którą kryje się twarz innego protoplasty współczesnego państwa polskiego? Jeżeli bowiem senatorowie chcieli podkreślić konieczność wykluczenia dziedzictwa komunistycznego z porządku prawnego Rzeczypospolitej, niezrozumiałe było nazywanie powstałych i funkcjonujących po 1943 r. z nadania Moskwy struktur zarządzających częścią ludności, ziem oraz dóbr materialnych i niematerialnych przysługujących Rzeczypospolitej Polskiej państwem. Zwłaszcza że popadli w ten sposób w poważny problem terminologiczny, nazywając państwem organizację, która — jak sami to podkreślili - z założenia była niesuwerenna. Konsekwencją odmówienia danemu ciału korporacyjnemu przymiotu suwerenności jest bowiem przecież nie tylko czcze gdybanie o abstrakcjach, ale przede wszystkim zakwestionowanie jednego z filarów pozytywistycznego (czyli dominującego w Polsce) rozumienia prawa.

27 Ustawa Konstytucyjna z dnia 19 lutego 1947 r. o ustroju i zakresie działania najwyższych organów Rzeczypospolitej Polskiej (Dz.U. z 1947 r. Nr 18, poz. 71 z późn. zm.).

28 Ustawa z dnia 17 marca 1921 r. - Konstytucja Rzeczypospolitej Polskiej (Dz.U. z 1921 r. Nr 44, poz. 267 z późn. zm.). 
Z drugiej strony takie podejście senatorów (tj. uznanie Polski komunistycznej za ułomne, ale jednak państwo) pozwala nam dostrzec faktyczną pozorność wcześniejszej deklaracji o niepodważalności „legalnie mocy prawnej Ustawy Konstytucyjnej Rzeczypospolitej Polskiej z dnia 23 kwietnia 1935 r. oraz opartego na niej porządku prawnego", gdyż nakazuje uznać regulacje tworzone przez komunistów za — być może - ułomne, ale jednak za prawo, które jest wiążące dla współczesnych i zastępujące skutecznie wcześniejszy i równoległy porządek prawny zakorzeniony w Konstytucji kwietniowej. Jak z tego wynika, Senat, kształtując treść uchwały, nie zakładał w rzeczywistości jakiejkolwiek możliwości przywrócenia sankcji państwowej systemowi normatywnemu tworzonemu przez władze II Rzeczypospolitej (przedwrześniowe i emigracyjne) w stopniu większym, niż zezwoliło na to wcześniej ,niedemokratyczne państwo o totalitarnym systemie władzy”29. Nie przewidywał też $\mathrm{w}$ jakiejkolwiek mierze nie tylko sugerowania pozostałym organom państwowym ${ }^{30}$, lecz nawet narzucenia samemu sobie uznawania mocy wiążącej Konstytucji kwietniowej. Taki sens miało, naszym zdaniem, niby kategoryczne sformułowanie, ,że akty normatywne stanowione przez niesuwerennego prawodawcę w latach 1944-1989 pozbawione są mocy prawnej”, ponieważ zostało ono jednocześnie zaopatrzone w zastrzeżenie, że dotyczy to tylko takich aktów, które „godziły w suwerenny byt państwa polskiego lub są sprzeczne z zasadami prawa uznawanymi przez narody cywilizowane". Ale nawet takie zawężone zakwestionowanie mocy prawnej niektórych działań normotwórczych rządców komunistycznych zostało dodatkowo osłabione uwagą, że

nieważność wspomnianych aktów normatywnych rangi ustawowej wymaga stwierdzenia ustawowego, a innych aktów normatywnych — decyzji właściwych organów władzy państwowej ${ }^{31}$.

29 Znamienna jest w tym kontekście znajdująca się na stronie Sejmu RP baza polskich aktów prawnych występująca pod nazwą Internetowy System Aktów Prawnych (ISAP, http://isap. sejm.gov.pl/). Nie znajdziemy w niej aktów prawnych publikowanych w Dzienniku Ustaw w latach 1940-1943. Akty wydawane w II Rzeczypospolitej w większości wypadków zostały określone jako „przedwojenne nieobowiązujące” (łącznie z Konstytucją kwietniową, Dz.U. z 1935 r. Nr 30, poz. 227). Tylko te akty, które reżim komunistyczny już wcześniej uznał za użyteczne dla swego funkcjonowania, mają dziś status uchylonych lub nawet obowiązujących (odnosi się to np. do wydanego pod rządami Konstytucji kwietniowej prawa czekowego i wekslowego). Zatem już konstrukcja owej bazy danych (stworzonej i administrowanej pod kontrolą Sejmu RP) dobitnie ukazuje całkowite uzależnienie mentalne i ideowe współczesnych od zmian wprowadzonych przez reżim komunistyczny. Nawet dziś, teoretycznie w państwie, które odrzuca dziedzictwo totalitarne, okazuje się, że rozstrzygnięcia podjęte przez totalitarystów determinują myślenie o prawie.

30 Nie mógł zresztą w tym trybie tego uczynić, gdyż uchwały Senatu nie znajduje się w konstytucyjnym katalogu źródeł prawa ustalonym w art. 87, ust. 1 (rozszerzonym o „prawo miejscowe” w ust. 2) Konstytucji Rzeczypospolitej Polskiej (Dz.U. z 1997 r. Nr 78, poz. 483 z późn. zm.).

$31 \mathrm{~W}$ uchwale złożono ponadto deklarację o konieczności przywrócenia (dokładniej brzmiało to tak: „Zapewnić równocześnie należy przywrócenie”; zdajemy sobie sprawę, że „konieczność przywrócenia” jest tylko jedną z możliwych interpretacji cytowanego zwrotu), „praw niesłusznie odebranych oraz ochronę praw nabytych, na podstawie uznanych za nieważne aktów normatywnych, chyba że nabycie było niegodziwe". Nawet w tej deklaracji widzimy podstawowy problem 
Tym samym w sposób pośredni potwierdzono zasadę domniemania mocy wiążącej aktów normatywnych wydawanych przez „niedemokratyczne państwo o totalitarnym systemie władzy", a co za tym idzie implicite przyznano, że III Rzeczpospolita jest pod względem prawnym potomkiem reżimu ustanowionego przez Związek Radziecki, nie zaś — jak oficjalnie w uchwale sugerowano - II Rzeczypospolitej. Ironia omawianej uchwały Senatu RP, a za jej pośrednictwem samej retoryki ciągłości, objawiała się zatem w cytowanych sformułowaniach z pełną wyrazistością. Wskażmy tu jeszcze, że uchwała Senatu nie stała się w jakiejkolwiek mierze wskazaniem dla zmiany linii interpretacyjnych w orzecznictwie sądowym, a w szczególności nie dała impulsu do wypracowania jakiejś polskiej wersji formuły Radbrucha. Także ten brak konsekwencji w sferze publicznej uchwały świadczy o jej ironicznym charakterze.

O ile w obu omówionych przypadkach retoryka ciągłości starała się jeszcze nałożyć na władze III Rzeczypospolitej maskę kontynuatorki Polski przedwojennej, o tyle po przyjrzeniu się wypowiedziom sądów i Trybunału Konstytucyjnego można jednoznacznie stwierdzić, że na płaszczyźnie judykatury nie istniał (i wciąż nie istnieje) nawet zamiar stwarzania pozorów takiej ciągłości. Wręcz przeciwnie, istnieje pełna akceptacja konstrukcji zakładającej, że III Rzeczpospolita pod względem prawnym jest kontynuatorką Polski komunistycznej, honorującą podjęte przez totalitarny reżim strategiczne rozstrzygnięcia co do zakresu akceptowalności tradycji II Rzeczpospolitej. Najbardziej lapidarnie ujął to Sąd Apelacyjny w Warszawie w wyroku z dnia 4 kwietnia 2013 r. (sygn. akt I ACa 815/12; publ. Legalis):

Dekret z dnia 26 października 1945 roku o własności i użytkowaniu gruntów na obszarze m. st. Warszawy (Dz.U. Nr 50, poz. 279) jest legalnym aktem prawnym, a zmiany własnościowe dokonane na jego podstawie stały się elementem stosunków prawnych podmiotów prawa prywatnego.

Sąd nie pokusił się w tym wypadku nawet o szersze uzasadnienie tej tezy: jest legalny, bo inne sądy oraz Trybunał Konstytucyjny nie mają co do tego wątpliwości w przypadku innych aktów nacjonalizacyjnych. I w pewnej mierze ów Sąd Apelacyjny miał rację: ani TK, ani Sąd Najwyższy, ani też Naczelny Sąd Administracyjny nigdy nie odważyły się na zakwestionowanie prawodawczych

ironiczny elit III Rzeczypospolitej: faktyczne uznanie za poprawne zmian, jakie zaszły na ziemiach polskich po 1943 r. zamaskowane retoryką ciągłości z Polską przedwojenną. Kwestia ta przebija się przede wszystkim w krótkim sformułowaniu dotyczącym ochrony „,praw niesłusznie odebranych”. Oznacza ono bowiem, że narzucone przez „niedemokratyczne państwo o totalitarnym systemie władzy" odarcie z praw było dopuszczalne, a naganne było tylko w takim zakresie, w jakim odbieranie owych praw można byłoby określić jako „niesłuszne”. Tę samą konstrukcję ukrytej akceptacji zmian można odnaleźć w cytowanej wcześniej formule dotyczącej nieważności niektórych aktów, w ramach której senatorowie za nieważne uznawali m.in. tylko akty, doprowadzające do „niesprawiedliwego pozbawienia własności”. 
uprawnień totalitarnego, niesuwerennego i stanowiącego — jak to ujął Senat RP — część światowego systemu komunistycznego reżimu.

Ten sam Sąd w orzeczeniu wydanym w innej sprawie blisko trzy tygodnie później (24 kwietnia 2013 r.; sygn. akt I ACa 1350/12; publ. Legalis) zdecydował się jednak na kilka dodatkowych słów wyjaśnienia, które warto przytoczyć:

Nie umniejszając znaczenia zastrzeżeń, jakie w teorii prawa ustrojowego są podnoszone w stosunku do uprawnień Państwowego Komitetu Wyzwolenia Narodowego dotyczących stanowienia prawa, podnieść należy, że akty prawne, w tym dekrety wydawane w latach 40 . przez wskazany organ faktycznie wytworzyły podstawę ukształtowania się systemu prawnego obowiązującego w Polsce po drugiej wojnie światowej, także w sferze stosunków własnościowych. Nacjonalizacja nieruchomości rolnych i leśnych, jaka została przeprowadzona dekretem PKWN z dnia 6 września 1944 r. o przeprowadzeniu reformy rolnej, pozbawiając własności przedwojennych właścicieli, wytworzyła stan prawny, który był podstawą funkcjonowania uczestników obrotu prawnego w okresie poprzedzających zmiany wprowadzone do kodeksu cywilnego nowelą lipcową z 1990 r. i do chwili obecnej stanowi element obowiązującego w Polsce systemu prawego, jest bowiem jedyną podstawą uznania, że Skarb Państwa jest obecnie właścicielem tych wszystkich nieruchomości, które zostały objęte działaniem powołanego dekretu [...]. [...] legislacyjna działalność PKWN nie podlega bowiem weryfikacji aktualnie obowiązującymi instrumentami kontroli konstytucyjnej, zaś skutki, które spowodował dekret o przeprowadzeniu reformy rolnej, nie mogą być obecnie uznane za wywołane bezprawnie.

Przytoczony krótki fragment uzasadnienia jednego z orzeczeń Sądu Apelacyjnego w Warszawie zawiera interesujące spostrzeżenia i sformułowania. Przede wszystkim Sąd ów, stosując odpowiednie zabieg erystyczne („nie umniejszając”; przeciwstawienie czyichś „teorii” własnej — w domyśle prawidłowej, bo rzeczywistej, a nie teoretycznej — działalności), odrzucił jako bezprzedmiotowe (bez wyjaśnienia podstaw odrzucenia) wątpliwości podnoszone przez „teorię prawa ustrojowego" wobec PKWN ${ }^{32}$. W konsekwencji przyjął w sposób bezdyskusyjny, że PKWN miał moc prawodawczą, a zmiany wprowadzane od 1944 r. wywołały skutki zarówno faktyczne, jak i prawne, które muszą być uznane, co do zasady, za niemożliwe do zakwestionowania jako źródła prawa. Tym samym potwierdził, że akty reżimu komunistycznego są wiążące także dla sądów III Rzeczypospolitej, jak też, że obecne organy sądowe nie mają kompetencji do badania legalności owych aktów zarówno w aspekcie formalny, jak i materialnym. Reasumując, można zatem stwierdzić, że cytowany fragment jest ważny właśnie dlatego, że pozwala na zrekonstruowanie czterech podstawowych przesłanek jednolitego (jak się wkrótce okaże) stanowiska judykatury w kwestii ciągłości prawnej między III Rzeczypospolitą a Polską komunistyczną i II Rzeczypospolitą:

1. Zastrzeżenia co do legalności władz wprowadzonych, kontrolowanych i chronionych przez Moskwę (oraz tym samym zastrzeżenia co do ich uprawnień prawodawczych) mają charakter wyłącznie akademickich dywagacji, bez jakiegokolwiek wpływu na moc wiążącą stanowionych przez nie aktów normatywnych.

${ }^{32}$ Na marginesie można zauważyć, że w opublikowanej wersji uzasadnienia popełniono błąd w rozwinięciu skrótu — literze P przypisano znaczenie Państwowy. 
2. Akty prawne, w tym Konstytucja kwietniowa, legalnych władz II Rzeczypospolitej nie mają żadnego znaczenia dla systemu normatywnego sankcjonowanego przez sądy III Rzeczypospolitej, chyba że reżim komunistyczny je recypował $\mathrm{i}$ w ten sposób nadał im przymiot prawa.

3. Legislacyjnej działalności reżimu komunistycznego nie można „weryfikować" narzędziami stosowanymi w państwie prawa.

4. Dla stwierdzenia, że dane akty normatywne są aktami prawnymi, nie jest istotna legalność ich źródła ani praworządność ich procedowania, ani nawet prawość i sprawiedliwość ich treści, albowiem jedynym miernikiem ich prawnego charakteru jest ich wcześniejsze usankcjonowanie przez siłę. Innymi słowy, w opinii polskich sądów porządek konkretny poprzedza i warunkuje porządek normatywny, pod warunkiem jednak, że jest to porządek zaprowadzony przez rządców komunistycznych.

To schmittowskie, decyzjonistyczne podejście (trudno zresztą orzec, w jakim stopniu uświadomione) nie cechowało wyłącznie Sądu Apelacyjnego w Warszawie. Dla przykładu, Wojewódzki Sąd Administracyjny w Warszawie w uzasadnieniu wyroku z dnia 17 marca 2015 r. (sygn. akt I SA/Wa 2915/14; publ. Legalis) stwierdził:

Współczesna wykładnia przepisów tego dekretu [tj. dekretu Polskiego Komitetu Wyzwolenia Narodowego z dnia 6 września 1944 r. o przeprowadzeniu reformy rolnej (Dz.U. z 1945 r. $\mathrm{Nr} 3$, poz. 13 z późn. zm.) — przyp. E.K., T.S.] [...] nie może być [...] oderwana od realiów prawnoustrojowych istniejących w 1944 r., a szczególnie od ówczesnej aksjologii systemu prawnego, którego dekret o przeprowadzeniu reformy rolnej był jednym z głównych elementów. W szczególności, nie można do wykładni przepisów dekretu o przeprowadzeniu reformy rolnej przykładać współczesnych konstytucyjnych standardów państwa prawnego i tworzenia prawa dla osiągania celów, które w sferze prawnej wynikają przede wszystkim z obowiązującej obecnie Konstytucji RP.

Zwróćmy tu przede wszystkim uwagę, że w tym wypadku kwestia uprawnień prawodawczych oraz problematyka legalności dekretu nacjonalizacyjnego nie odgrywała dla sędziów WSA żadnej roli — oba zagadnienia uznane zostały implicite za pozytywnie przesądzone. W cytowanym orzeczeniu sąd interesował się zatem wyłącznie ustaleniem zasad interpretacji treści przedmiotowego aktu oraz możności dokonania oceny zgodności owej treści z zasadami państwa prawa. Zauważmy przy tym, że odpowiedź sędziów w odniesieniu do wspomnianych dwóch zagadnień tylko na pierwszy rzut oka może się wydać kuriozalna — sąd III Rzeczypospolitej nie tylko nie jest władny stosować narzędzi egzegetycznych służących do ochrony praw obywateli w państwie prawa przy interpretacji aktów tworzonych przez totalitarny reżim, lecz nawet jest zmuszony do uwzględniania (akceptacji) komunistycznej, totalitarnej ,aksjologii systemu prawnego”. Pogląd ten przestanie jednak dziwić, gdy z jednej strony pojawi się świadomość leżącego u jego podstaw niewyartykułowanego wprost założenia o ciągłości normatywnej między Polską komunistyczną a III Rzecząpospolitą, a z drugiej zaś to, że polskie 
sądy jedynie w sprawach — nazwijmy to tak — bezpiecznych, czyli niewymagających głębszej refleksji nad naturą prawa, zdają się reprezentować ideę państwa prawa (i to raczej w pozytywistycznej niż iusnaturalistycznej odmianie), w sytuacjach natomiast skrajnych, zmuszających do podjęcia egzystencjalnych decyzji i ujawniających tym samym — zgodnie z tezą Sørena Kierkegaarda ${ }^{33}$ — prawdziwe oblicze zwyczajnych rzeczy, sądy te okazują się admiratorami Schmittowskiej koncepcji ustrojowej. Albowiem wyłącznie takie stanowisko w naszym przekonaniu jest w stanie wyjaśnić nie tylko zaprzeczenie możliwości badania legalności aktów totalitarnego reżimu czy możności ich interpretacji z punktu widzenia standardów państwa prawa, ale przede wszystkim pogląd o konieczności uwzględniania w toku współczesnych postępowań sądowych „aksjologii” systemu komunistycznego.

Rzeczony decyzjonistyczny sposób rozumienia prawa nie był wymysłem WSA w Warszawie, lecz był poprzedzony ważnymi rozstrzygnięciami podejmowanymi przez Sąd Najwyższy i Trybunał Konstytucyjny. Istotny (z uwagi na swoistą dosadność) przykład takiego podejścia można odnaleźć w uzasadnieniu wyroku Sądu Najwyższego - Izby Cywilnej z dnia 16 listopada 2004 r. (sygn. akt III CK 322/04; publ. Legalis), w którym na podniesioną przez skarżącego w kasacji wątpliwość, czy dekret o reformie rolnej, ze względu na niekonstytucyjny charakter PKWN, może być uznany za źródło prawa, odpowiedział następująco:

Kwestii, czy dekret o reformie rolnej jest źródłem powszechnie obowiązującego prawa Rzeczypospolitej Polskiej, nie można ograniczać jedynie do zagadnienia samej legitymizacji PKWN i wydanego przezeń dekretu. Ważne znaczenie mają także skutki tego aktu prawnego. Dlatego ocena aksjologiczna dekretu o reformie rolnej, czy też jego formalnej legitymizacji, dziś najczęściej nie może już prowadzić do kwestionowania samych skutków. Dekret o reformie rolnej, który wszedł w życie z dniem 13 września 1944 r., spowodował zasadnicze zmiany w strukturze własności nieruchomości ziemskich. Upływ czasu, z punktu widzenia prawa nieobojętny, nadał im trwałość i obecnie stanowią one podstawę ekonomicznej i społecznej egzystencji znacznej części społeczeństwa. [...] Z przedstawionych powodów ${ }^{34}$ nie można po-

33 Zob. T. Scheffler, op. cit., s. 383-384.

34 Oprócz cytowanych argumentów SN podniósł jeszcze dwa inne - pierwszy to utrwalona, zgodna linia orzecznicza (poparł to przywołaniem 9 orzeczeń TK, SN i NSA), drugi to teza, że „Skutki, jakie wywołał dekret o reformie rolnej respektował ustawodawca. Świadczą o tym nowelizacje tego dekretu i ustawy odwołujące się do jego unormowań. Przykładowo można wskazać na art. 4 i art. 7 ustawy z dnia 13 lipca 1957 r. o obrocie nieruchomościami rolnymi (Dz.U. Nr 39, poz. 172 ze zm.), art. 5 ustawy z dnia 17 maja 1990 r. o podziale zadań i kompetencji określonych w ustawach szczególnych pomiędzy organy gminy a organy administracji rządowej oraz zmianie niektórych ustaw (Dz.U. Nr 34, poz. 198 ze zm.), czy art. 216a ustawy z dnia 21 sierpnia 1997 r. o gospodarce nieruchomościami (tekst jedn.: Dz.U. z 2000 r. Nr 46, poz. 543 ze zm.)”. Szczególnie intrygujące w kontekście naszej tezy o ciągłości jest przywołanie zmian wprowadzonych w $1957 \mathrm{r}$. na równi ze zmianami wprowadzonymi po $1989 \mathrm{r}$. 
dzielić poglądu skarżącego, że dekret o reformie rolnej nie ma mocy obowiązującego prawa, skoro spowodował on skutki sięgające głęboko w sferę dzisiejszych stosunków własnościowych i w sferę ochrony praw dobrze nabytych.

Jak możemy przeczytać, dla Sądu Najwyższego sprawą oczywistą było zatem widzenie prawa jako zjawiska pochodnego wobec siły, gdyż za deklaracją o niemożności ograniczenia dyskusji ,jedynie do zagadnienia samej legitymizacji PKWN” kryło się odrzucenie jakiegokolwiek rozważania zagadnienia „legitymizacja PKWN" czy oceny aksjologicznej dekretu o reformie rolnej. Zwróćmy uwagę, że mieliśmy tu do czynienia z kolejny przykładem ciekawego zabiegu erystycznego. Przy literalnym odczytaniu wypowiedź SN sugerowała uznanie konieczności wprowadzenia do dyskusji o mocy wiążącej dekretów reżimu komunistycznego innych czynników niż tylko legitymacja organu wydającego. Owe odmienne przesłanki musiałyby jednak znajdować się obok, a nie zamiast kwestii legalności. Jak widzimy jednak chociażby z następnego cytowanego zdania, faktyczna intencja SN była odmienna, ponieważ kwestia legalności jako element istotny dla sprawy zupełnie została odrzucona, a w jej miejsce weszło wyłącznie zagadnienie faktów dokonanych — tego, że zmiany dotyczące własności zaszły i zdaniem sądu stały się zasadniczo nieodwracalne, jeżeli przeprowadzono je formalnie poprawnie (tzn. zgodnie z literalnym brzmieniem dekretu). Innymi słowy, SN stanął na stanowisku, że dla rozstrzygania nie ma żadnego znaczenia legalność aktu normatywnego czy jego zgodność ze standardami współczesnego państwa prawa (lub chociażby z rzekomo honorowaną przez komunistów Konstytucją marcową z 1921 r.), którym przecież ów Sąd podlega i na straży przestrzegania których stoi. Jedynym czynnikiem wiążącym dla Sądu ma być zatem porządek konkretny, który został zaprowadzony po 1943 r., gdyż to on właśnie warunkuje jego zdaniem porządek normatywny.

Przywołane stanowisko SN było w pełni zgodne z poglądem wyłożonym wcześniej przez Trybunał Konstytucyjny. W postanowieniu z dnia 28 listopada 2001 r. (sygn. akt SK 5/01; publ: Orzecznictwo Trybunału Konstytucyjnego rok 2001, nr 8, poz. 266) sędziowie TK stwierdzili:

Brak konstytucyjnoprawnej legitymacji takich organów jak PKWN, KRN, Rząd Tymczasowy, a także wątpliwa legitymacja później istniejących organów, nie może nieść konsekwencji w postaci ignorowania faktu, że efektywnie wykonywały one władzę państwową. Akty normatywne tych organów były podstawą rozstrzygnięć indywidualnych, które m.in. ukształtowały strukturę własnościową w obszarze własności rolnej, a także stosunki prawne w innych dziedzinach życia społecznego. Upływ czasu, który z punktu widzenia prawa nie jest zjawiskiem obojętnym, nadał tym stosunkom trwałość i dziś są one podstawą ekonomicznej i społecznej egzystencji znacznej części społeczeństwa polskiego.

Także Trybunał - jak mogliśmy zatem przeczytać — stanął na Schmittowskim stanowisku, że o tym, czy mamy do czynienia z prawem czy też nie, decyduje „efektywne wykonywanie władzy państwowej”. Ponownie widzimy więc decyzjonistyczne ujęcie prawa, które w polskiej tradycji zostało dobitnie jeszcze 
w okresie przedwojennym wyrażone w okresie zamachu majowego z $1926 \mathrm{r}$. $\mathrm{Z}$ tego punktu widzenia można byłoby nawet mówić o ciągłości ideowej między II a III Rzecząpospolitą, niemniej jednak nie wydaje się, aby owa zbieżność była uświadomiona, gdyż brakowalo jakichkolwiek odniesień w wypowiedziach judykatury, które - chociażby aluzyjnie - pozytywnie odwoływałyby się do innych elementów dziedzictwa myśli polityczno-prawnej Józefa Piłsudskiego lub które wskazywałyby na świadome nawiązanie do obozu piłsudczykowskiego właśnie w obszarze relacji polityki i prawa. Paralelność ta wynikała raczej — jak możemy jedynie się domyślać - $\mathrm{z}$ intuicyjnego, przedracjonalnego ujęcia natury prawa, na który następnie nakładana jest postracjonalizująca argumentacja, która ma sugerować, że decyzja sądu bądź trybunału mieści się jeszcze w tradycji państwa prawa. To stąd $\mathrm{w}$ uzasadnieniach pojawiały się formuły słowne sugerujące rzekome rozważanie kwestii legalności oraz opieranie w ostateczności rozstrzygania na poziomie werbalnym wyłącznie na przesłance upływu czasu, z której wynikać miałaby jakoby niemożność zakwestionowania skutków zmian własnościowych wprowadzonych przez reżim komunistyczny. A przecież właśnie w tym aspekcie możemy zauważyć wątpliwy charakter owego argumentu: roszczenia windykacyjne, jeżeli dotyczą nieruchomości (także w regulacjach tworzonych przez komunistów — por. art. 223 § 1 k.c. w brzmieniu pierwotnym z 1964 r.), nie przedawniają się. Istnieje wprawdzie instytucja zasiedzenia, jednak do wywołania skutków przez nią przewidzianych przeprowadzona musi być określona procedura prowadząca do jednej z form legalnego „wywłaszczenia”. Już chociażby to wskazuje, że sam upływ czasu jest niewystarczającą przesłanką do stwierdzenia nastąpienia transferu prawa własności. Przekonuje to do podniesienia wątpliwości, czy cytowane orzeczenia sądów i Trybunału Konstytucyjnego nie mają również charakteru ironicznego, z tym jednak zastrzeżeniem, że maskowana byłaby w tym wypadku relacja między normatywnym i ideowym dziedzictwem reżimu komunistycznego (ochrona praw „dobrze nabytych”, uwzględnianie aksjologii poprzedniego systemu) a systemem III Rzeczypospolitej. Owa ironiczna natura rozstrzygnięć judykatury wyjaśniałaby też totalne odrzucenie dziedzictwa prawnego władz II Rzeczypospolitej poza tymi elementami, które uzyskały wcześniejszą akceptację reżimu komunistycznego.

Na koniec artykułu zwróćmy jeszcze krótko uwagę na wybrane wypowiedzi przedstawicieli środowisk prawniczych pojawiające się na łamach prasy popularnej i naukowej u progu III Rzeczypospolitej. Jak można zauważyć, zagadnienia ciągłości ustrojowej państwa polskiego, a w szczególności relacji między III Rzecząpospolitą a tradycją prawną PRL-u i okresu międzywojnia, zaprzątały w pewnej mierze ich uwagę. Co warte podkreślenia już w tym miejscu: żaden przedstawiciel establishmentu prawniczego nie domagał się przestrzegania przez sądy i administrację aktów normatywnych wydawanych przez legalne organy państwa polskiego działające na emigracji oraz aktów normatywnych wydanych przed wrześniem 1939 r. w II Rzeczypospolitej, które nie uzyskały akceptacji 
reżimu komunistycznego, jak też nie postulował uznania za nieistniejące aktów wydawanych przez rządców z nadania Związku Radzieckiego. Ich uwaga była skupiona wokół kwestii, czy utrzymać w mocy tymczasowe rozwiązania ustrojowe, doprowadzając do zmian ewolucyjnie, czy też uchylić ustawę zasadniczą z 22 lipca 1952 r. oraz istotnie i radykalnie zmodyfikować ówczesny system. Co ciekawe, na ogół wyrażano jednoznaczne przekonanie o konieczności derogacji modelu „socjalistycznego" na rzecz nowego i „wymownie” brzmiącego „demokratycznego państwa prawnego", czego elementem miały być przeprowadzone w wyniku decyzji podjętych podczas obradach Okrągłego Stołu i po wyborach z 4 czerwca 1989 r. nowelizacje konstytucji z 1952 r., przekształcające jakoby monocentryczny system rządzenia w pluralistyczny ład polityczny ${ }^{35}$.

Przykładowo, w opinii prof. Wojciecha Sokolewicza uchwalona 7 kwietnia 1989 r. ustawa o zmianie Konstytucji dokonała „najgłębszych” zmian tego aktu w jego historii obowiązywania, ujawniając „nową filozofię rządzenia”, gwarantującą jej praktyczne urzeczywistnienie. Był też przeświadczony, że nowela konstytucyjna z 29 grudnia 1989 r. stworzyła ,prawne przesłanki jakościowej zmiany tego ustroju", albowiem układ parlamentarnych sił politycznych po czerwcowych wyborach doprowadził do „radykalnych” reform ustrojowych ${ }^{36}$. Podobnych przerysowanych wypowiedzi, oceniających jako głębokie i radykalne zmiany, które wprowadzano doraźnie i powierzchownie, było w okresie przełomu więcej. I to pomimo dostrzegania zachowania w treści konstytucji elementów frazeologii komunistycznej i PRL-owskich reliktów instytucjonalnych, które mogły jednak świadczyć o utrzymaniu w mocy ciągłości systemowej ${ }^{37}$. Jako dowód braku zerwania z przeszłością wskazywano przy tym najczęściej nie tylko zachowanie

35 Z taką opinią możemy się spotkać w artykułach: J. Zakrzewska, Nowa Konstytucja Rzeczpospolitej, „Państwo i Prawo” (dalej: PiP) 1990, nr 4, s. 3; W. Sokolewicz, Rzeczpospolita Polska - demokratyczne państwo prawne (uwagi na tle ustawy z 29 XII 1989 o zmianie Konstytucji), PiP 1990, nr 4, s. 12 n.; Z. Czeszejko-Sochacki, Projekt nowej konstytucji (przegląd zagadnień węzłowych), PiP 1991, nr 7, s. 3; M. Wyrzykowski, Legislacja - demokratyczne państwo prawa, radykalne reformy polityczne i gospodarcze, PiP 1991, nr 5, s. 17-20; K.M. Pospieszalski, Z. Ziembiński, Konstytucja rocznicowa czy konstytucja wiekopomna?, „Ruch Prawniczy, Ekonomiczny i Socjologiczny" 1991, z. 1, s. 20; K. Działocha, Państwo prawne w warunkach zmian zasadniczych systemu prawa RP, PiP 1992, nr 1, s. 13.

36 W. Sokolewicz, Kwietniowa zmiana konstytucji, PiP 1989, nr 6, s. 3; idem, Rzeczpospolita Polska..., s. 12. Gwoli ścisłości należy jednak zaznaczyć, że autor ten wskazał także na niespójności systemowe wynikające $\mathrm{z}$ wprowadzanych zmian konstytucyjnych, które mogły rodzić liczne trudności w procesie stosowania prawa, obniżając tym samych jego prestiż (idem, Kwietniowa zmiana ..., s. 8-9). Podobną opinię wyrazili K.M. Pospieszalski, Z. Ziembiński, op. cit., s. 22, 24; oraz A. Kubiak, Państwo prawne - idea, postulaty, dylematy, PiP 1991, nr 7, s. 15. W opinii ówczesnej rzecznik praw obywatelskich Ewy Łętowskiej owe rozbieżności w prawie i towarzyszące im problemy natury pragmatycznej sprzyjały niepokojącemu zjawisku ,agnostycyzmu” czy też „nihilizmu konstytucyjnego" w zachowaniach organów państwowych (eadem, Wystapienie Rzecznika Praw Obywatelskich w Sejmie, PiP 1990, nr 5, s. 9-10).

37 Podobną tezę wyraził M. Smolak, Wyktadnia prawa a zmiana spoleczno-polityczna, [w:] Studia z filozofii prawa, red. J. Stelmach, Kraków 2001, s. 163. 
w tytule aktu konstytucyjnego (również po grudniowej noweli) niezbyt chwalebnej daty uchwalenia (22 lipca) konstytucji z 1952 r., która nieprzypadkowo przecież nawiązywała do „niechlubnej” rocznicy narzuconego przez władze ZSRR Manifestu Lipcowego, ale też pozostawienie do grudniowych zmian nazwy państwa, którego najwyższe organy (prezydent, Sejm, Senat) terminologicznie reprezentowały PRL, nadal określaną mianem państwa socjalistycznego ${ }^{38}$.

Co więcej, jak zgodnie zauważali Karol M. Pospieszalski i Zygmunt Ziembiński oraz Wojciech Sokolewicz, ówcześni prawodawcy, ale także specjaliści z zakresu prawa konstytucyjnego, nie wykazywali się klarownie sprecyzowanym pomysłem dotyczącym koncepcji państwa, poza deklarowaną koniecznością negacji jego socjalistycznego charakteru ${ }^{39}$. Na poziomie akademicko-publicystycznym zastanawiano się, czy państwo polskie po 1989 r. powinno ustrojowo-prawnie nawiązać do przedwojennej tradycji II Rzeczypospolitej, odwołując się do konstytucyjnych unormowań z 17 marca 1921 r. lub też z 23 kwietnia 1935 r., czy na kanwie ówczesnych, tymczasowych rozwiązań zakorzenionych w PRL-u stworzyć znacząco zmodyfikowaną i optymalną nową konstrukcję, czy też wreszcie całkowicie odrzucić dotychczasowy porządek i wykreować nieobciążoną socjalistyczną przeszłością ustawę zasadniczą? Można pokusić się o stwierdzenie, że konstruktywnych rozważań w tym kierunku raczej nie podjęto podczas posiedzeń w Magdalence. Również teoretycy i praktycy prawa oraz inne opiniotwórcze środowiska przy braku konsensusu w sprawie świadomego uznania kontynuacji tradycji jednego z dwóch systemów prawnych obowiązujących przed wojną ${ }^{40}$ nie zdołali przyjąć radykalnej postawy zrywającej z dorobkiem konstytucyjnym powstającym od $1944 \mathrm{r}$. Wprawdzie niektórzy wyrażali przekonanie o konieczności odcięcia się od tradycji

38 Utrzymanie w mocy owych istotnych ze względów ustrojowych fragmentów Konstytucji miało być jakoby konsekwencją porozumień „okrągłego stołu” z 5 kwietnia 1989 r. Przecież w udostępnionych oficjalnie tekstach owych porozumień nie odnajdziemy ustaleń w tej materii. Por. Porozumienia okragłego stołu, [w:] Konstytucje Polskie 1918-1998, oprac. T. Mołdawa, Warszawa 1999, s. 285-291.

39 Warto zauważyć, że prof. J. Zakrzewska, wykazując potrzebę zmiany nieprzystającej do realiów społecznych Konstytucji z 1952 r., postulowała jednocześnie koncepcję państwa naznaczonego elementami socjalnymi (eadem, op. cit., s. 11). Podobne stanowisko zajął S. Zawadzki, Nowa konstytucyjna definicja polskiej państwowości, PiP 1990, nr 5, s. 22-23. Gwoli ścisłości zauważmy, że pojęcie „socjalizm” było w dyskusjach traktowane jako słowo-wytrych: każdy się nim posługiwał, ale z kontekstu używania wynikało, że nadawano mu bardzo różne znaczenie; najczęściej jednak posługiwano się nim jako synonimem systemu ukształtowanego w PRL. W tym znaczeniu deklaracje o negacji socjalizmu były ironiczne, ponieważ z negacją socjalizmu nie łączono negacji masy normatywnej wytworzonej przez reżim komunistyczny.

40 J. Zakrzewska pisała o społecznych sentymentach dla Konstytucji marcowej, którą z kolei profesor prawa międzynarodowego Ludwik Dembiński uznał za niedojrzałą i słabą (por. eadem, op. cit., s. 4; L. Dembiński, Uwagi o ustroju III Rzeczpospolitej, „Tygodnik Powszechny” 1990, nr 28, s. 1). W opiniach odnoszących się zaś do Konstytucji kwietniowej można się spotkać z krytycznym nastawieniem zarówno w kwestii legalności jej uchwalenia, jak i do jej antydemokratycznego charakteru (por. ibidem; K.M. Pospieszalski, Z. Ziembiński, op. cit., s. 20). 
PRL-u (czego jednym z kluczowych dowodów miało być omówione wcześniej symboliczne przekazanie insygniów państwowych) ${ }^{41}$, a nawet postulowali pójście swoistą „trzecią drogą" ustrojową (ani PRL, ani II RP, tylko nowe demokratyczne państwo prawa wzorowane na rozwiązaniach zachodnioeuropejskich) ${ }^{42}$, niemniej zdecydowana większość autorów proponowała implicite zachowanie ciągłości $\mathrm{z}$ ancien régime oraz wypracowanie $\mathrm{w}$ imię pewności i zaufania wobec majestatu prawa takich wartości i wykładni przepisów, które pozwoliłyby zachować w określonych sytuacjach i stosunkach prawnych dotychczasowy stan rzeczy ${ }^{43}$.

Dziwny stan, w którym znalazła się wówczas pod względem ustrojowo-prawnym Polska, dobrze oddawało stwierdzenie Pospieszalskiego i Ziembińskiego: „W stare naczynie wlano nową treść, wszakże stare naczynie budzi[ło] resentymenty" 44 . Jednej z głównych przyczyn owego stanu rzeczy Ziembiński poszukiwał w panującym nieprzerwanie od końca II wojny światowej socjalistycznym systemie politycznym i gospodarczym. Doprowadził on bowiem w jego opinii do zniszczenia właściwych społeczeństwu demokratycznemu postaw oraz zaburzył proces wyłaniania się i krążenia elit, które byłyby zdolne do opracowania szczegółowego i realnego programu ustrojowego. Ówczesne przemiany, jak też konstatował badacz, niestety uzasadniały prawdziwość tezy, że proces totalitaryzacji ustroju okazał się łatwiejszy do przeprowadzenia niż jego detotalitaryza$\mathrm{cji}^{45}$. Podobny pogląd wyłożył socjolog Jerzy Szacki, który na łamach „Res Publica" dowodził, że oddziaływanie przez blisko pół wieku PRL-owskiego ustroju na wszystkie dziedziny życia wraz z monopolem na ich kontrolę doprowadziło do rozkładu i dezorganizacji społeczeństwa. Przestrzegał zatem, by „socjalizmu model liryczny" (opisany przez socjologa i eseistę J. Strzeleckiego) nie został zamieniony na liryczny model demokracji ${ }^{46}$, gdyż ludzie oduczeni działania podmiotowego mogą nie rozeznać, co jest demokracją, a co jej ładną, artystyczną imitacją.

41 Por. K.M. Pospieszalski, Z. Ziembiński, op. cit., s. 20.

42 L. Dembiński, op. cit., s. 1.

43 Por. rozważania Andrzeja Wasilewskiego w kwestii doniosłości „gwarancji względnej ciągłości” porządku normatywnego, z którą ściśle łączył postulat ochrony zaufania, poczucia pewności prawa oraz jasności, obliczalności i przewidywalności działań państwa. W jego opinii wspomniane zasady powinny być przestrzegane $\mathrm{w}$ procesie stanowienia i stosowania prawa; odstąpienie od niech dopuszczalne było wyłącznie w „wyjątkowych” sytuacjach uzasadnionych nadzwyczajnymi potrzebami (idem, Aktualizacja porzadku prawnego — potrzeby i rygory, PiP 1992, $\mathrm{nr} 5$, s. 4). W rozumowaniu tym objawia się wyraźnie piętno retoryki ciągłości: prezałożenie uznające regulacje tworzone przez reżim komunistyczny za prawo. Nie ma tu miejsca na dyskusję czy dowody, gdyż teza o prawomocności działań spadkobierców PKWN stanowi aksjomat.

${ }^{44}$ K.M. Pospieszalski, Z. Ziembiński, op. cit., s. 20. To nawiązanie do biblijnej przypowieści o młodym winie i starych bukłakach pokazywało, że istniała wówczas (przynajmniej u niektórych przedstawicieli elit prawniczych) świadomość niebezpieczeństw związanych ze strukturalnonormatywnym zakotwiczeniem III Rzeczpospolitej w PRL-u.

45 Z. Ziembiński, ,Lex” a „,ius” w okresie przemian, PiP 1991, nr 6, s. 3-4. Por. też A. Wasilewski, op. cit., s. 3.

46 J. Szacki, Marzenia i rzeczywistość polskiej demokracji, „Res Publica” 1991, nr 5, s. 16-17. 
Co ciekawe, zarówno w przypadku Ziembińskiego, jak i Szackiego pomiędzy wierszami ich tekstów można było odczytać niepokój, czy nowe elity społeczne, ukształtowane przecież pod władztwem komunistycznym, będą w stanie porzucić stare nawyki i poprowadzić kraj do sfery wolności. Wprawdzie żaden z przywołanych autorów nie poczynił aluzji w tym zakresie, niemniej jednak ich obawy przywoływały na pamięć bajkę Ignacego Krasickiego pt. Ptaszki w klatce.

W tekstach poświęconych przekształceniom ustrojowym Polski po Okrągłym Stole ważnym zagadnieniem stało wypracowanie nowej aksjologii ugruntowującej zmiany ustrojowe. Uznawano to za warunek sine qua non z jednej strony wewnętrznej spójności treści nowych regulacji prawnych, a z drugiej — jasnego określenia ich legitymizacji, która dodatkowo gwarantowana byłaby klasycznymi regułami walidacyjnymi i egzegetycznymi oraz koncepcją zamkniętego systemu źródeł prawa. Podkreślano również konieczność znalezienia w praktyce prawniczej równowagi między lex a ius, czyli między „literą" a „duchem prawa” 47 . Autorzy publikujący w periodykach prawniczych podkreślali, że zwornikiem systemu nowych wartości postkomunistycznej Polski powinna się stać zasada „demokratycznego państwa prawnego", sformułowana w art. 1 znowelizowanej 29 grudnia 1989 r. wersji konstytucji ${ }^{48}$. Z niej z kolei, jak podkreślano, przy użyciu adekwatnej do przejściowych uwarunkowań wykładni normatywnej oraz politycznej można było wywieść zespół pożądanych cech prawidłowo funkcjonującego państwa. Ze wspomnianą naczelną zasadą (wywodzącą się z XIX-wiecznej niemieckiej doktryny Rechtsstaaat) utożsamiano zatem ideał praworządności, zwłaszcza formalnej, i legalności państwa na etapie tworzenia, jak też stosowania prawa, lecz także poddania kontroli konstytucyjnej aktów normatywnych obowiązujących obywateli ${ }^{49}$. Uznano, że ze względu na bezpieczeństwo i pewność prawa znacznie większą uwagę należy przywiązywać do litery prawa, nawet odziedziczonego po dotychczasowym reżimie politycznym (poza skrajnie niesprawiedliwymi rozstrzygnięciami), niż odwoływać się do zasad sprawiedliwości czy określonej moralności, które prof. Tadeusz Zieliński, senator I kadencji RP, traktował jako wyższego rzędu porządek prawny i nazwał go ,prawem pisanym na gwiazdach" ${ }^{\prime 50}$. Jak pisaliśmy już o tym w kontekście uchwały Senatu RP z 1998 r.: próby wprowadzenia do polskiego systemy odpowiednika niemieckiej

47 Zob. w szczególności J. Zakrzewska, op. cit., s. 11; Z. Ziembiński, op. cit., s. 4-5.

48 Zob. szerzej A. Wasilewski, op. cit., s. 3.

49 J. Wróblewski, Z zagadnień pojęcia i ideologii demokratycznego państwa prawnego (analiza teoretyczna), PiP 1990, nr 6, s. 3 n. Negatywne stanowisko wobec tej zasady przyjął polityk Jan Olszewski, którą sprowadził ją do reguły chroniącej komunistyczną nomenklaturę. Zob. szerzej J. Olszewski, Państwo przede wszystkim, „Rzeczpospolita” 1991, nr 153; oraz utrzymany w tym duchu artykuł profesora prawa, sędziego Sądu Najwyższego w latach 1990-1998, Adama Strzembosza, Rzeczpospolita Polska państwem prawnym - czy naprawdę?, „Rzeczpospolita” 1991, nr 234.

50 Wywiad z prof. T. Zielińskim pt. W poszukiwaniu nowego sensu prawa, „Rzeczpospolita” 1991, nr 157, s. 3. 
formuły Radbrucha były torpedowane przez zdecydowaną większość establishmentu prawniczego związanego z sądownictwem.

Podsumowując ten fragment artykułu, można powiedzieć, że sytuacja Rzeczypospolitej na przełomie lat 80 . i 90 . skłoniła specjalistów nauki i praktyki prawniczej do refleksji teoretycznej nad przyjęciem kompromisowej dla okresu transformacji aksjologii porządku prawnego. Podjęto również wysiłek poszukiwania doktryny prawnej w zakresie desuetudo oraz egzegezy przepisów uchwalonych pod rządami reżimu PRL, a nadal utrzymanych w mocy w okresie przemian społeczno-politycznych i gospodarczych. Analizowany materiał pozwolił zauważyć, że zdecydowana większość przedstawicieli elit zajęła wyraźnie umiarkowaną postawę wobec kompleksowych zmian na niwie prawnej. Pomimo zgodności w kwestii konieczności uchylenia Konstytucji z 1952 r. nie pojawiły się radykalne propozycje zerwania z dotychczasową doktryną i systemem normatywnym, co nierzadko uzasadniano tezą o stabilności i bezpieczeństwie państwa.

\section{$* * *$}

Po przeanalizowaniu wspomnianych na początku tekstu zdarzeniach symbolicznych i wybranego, choć reprezentatywnego orzecznictwa oraz po omówieniu wypowiedzi niektórych przedstawicieli establishmentu prawniczego możemy uznać za potwierdzoną wstępną tezę, że retoryka ciągłości ma faktycznie charakter ironiczny: za maską kontynuacji tradycji powstałego w 1918 r. niepodległego państwa polskiego kryje się rzeczywistość ciągłości z systemem normatywnym wytworzonym przez reżim wprowadzony na ziemie polskie z nadania Związku Radzieckiego $^{51}$. Dla jasności chcemy podkreślić, że nasza teza jest opisem, jest stwierdzeniem istnienia pewnego realnego zjawiska i że nie należy jej ujmować w kategoriach sądu wartościującego. Fakty mogą być niemile widziane, niemniej jednak w wypadku badań naukowych muszą być odkrywane i uwzględniane przy wtórnych wobec nich próbach oceny zjawisk społecznych. Stwierdzenie ironicznego charakteru retoryki ciągłości, osobliwie zaś analiza tego, co zostaje uznane za prawo, oraz dlaczego lub po co właśnie to, a nie co innego za prawo zostaje uznane, umożliwia oddzielenie rzeczywistych przełomów ustrojowych od ich imitacji. Jak bowiem trafnie zauważył w kontekście tworzenia się II Rzeczypospolitej Waldemar J. Wołpiuk:

51 Interesujący przykład pewnej ciągłości myślenia prawniczego między czasami przed 1989 r. i współczesnością na gruncie prawa karnego dostarczają wypowiedzi doktryny i judykatury na tle art. 256 k.k. Zob. szerzej T. Scheffler, Przestępstwo publicznego propagowania faszystowskiego lub innego totalitarnego ustroju państwa (art. 256 k.k.). Analiza doktrynologiczna wybranych wypowiedzi piśmiennictwa i judykatury. Część ogólna, „Studia nad Autorytaryzmem i Totalitaryzmem" 34, 2012, nr 3, s. 97-117. 
czasy przełomu dziejowego, odzyskiwania niepodległości budowanie nowej państwowości z reguły powodują nieprzydatność dawniej obowiązujących regulacji prawnych w nowych okolicznościach $^{52}$.

Porównanie tego, co wydarzyło się po 1943 r., z tym, co rozpoczęło się oficjalnie na przełomie 1988 i 1989 r., właśnie w podejściu do prawa udowadnia zatem nie tylko ironiczność retoryki ciągłości, lecz także pomaga zrozumieć naturę obu przełomów ${ }^{53}$.

\section{Bibliografia}

\section{Akty normatywne i pisma urzędowe}

Dekret Prezydenta Rzeczypospolitej z dnia 20 grudnia 1990 r. o zakończeniu działalności i rozwiązaniu Rządu Rzeczypospolitej na Uchodźstwie (Dz.U. z 1990 r. Nr 5, poz. 55).

Komunikat Kancelarii Cywilnej Prezydenta Rzeczypospolitej o przejeździe Prezydenta Rzeczypospolitej Ryszarda Kaczorows[kiego] z Londynu do Kraju oraz powitaniu w Warszawie w dniu 22.XII.[1990] r. (Dz.U. z 1990 r. Nr 5, dział nieurzędowy).

Komunikat Kancelarii Cywilnej Prezydenta Rzeczypospolitej o przewiezieniu z Londynu insygniów prezydenckich na Zamek Królewski w Warszawie (Dz.U. z 1990 r. Nr 5, dział nieurzędowy).

Konstytucja Polskiej Rzeczypospolitej Ludowej uchwalona przez Sejm Ustawodawczy w dniu 22 lipca 1952 r. (Dz.U. z 1952 r. Nr 33, poz. 232).

Konstytucja Rzeczypospolitej Polskiej z dnia 2 kwietnia 1997 r. (Dz.U. z 1997 r. Nr 78, poz. 483 z późn. zm.).

Obwieszczenie Państwowej Komisji Wyborczej z dnia 26 listopada 1990 r. o wynikach głosowania i wyniku wyborów Prezydenta Rzeczypospolitej Polskiej, zarządzonych na dzień 25 listopada 1990 r. (Dz.U. z 1990 r. Nr 83, poz. 483).

Obwieszczenie Państwowej Komisji Wyborczej z dnia 10 grudnia 1990 r. o wynikach ponownego głosowania i wyniku wyborów Prezydenta Rzeczypospolitej Polskiej (Dz.U. z 1990 r. Nr 85, poz. 499).

Orędzie Prezydenta Rzeczypospolitej Ryszarda Kaczorowskiego wydane w Londynie 21 grudnia 1990 r. (Dz.U. z 1990 r. Nr 5, dział nieurzędowy).

Podziękowanie Lecha Wałęsy za odznaczenie Polonia Restituta nadane przez Prezydenta RP na uchodźctwie JN Sokolnickiego, http://sokolnicki.republika.pl/html/wlesa podziekowanie.html.

Program uroczystości przekazania insygniów władzy prezydenckiej na Zamku Królewskim w Warszawie dnia 22 grudnia 1990 r. (Dz.U. z 1990 r. Nr 5, dział nieurzędowy).

Uchwała Senatu Rzeczypospolitej Polskiej z 16 kwietnia 1998 r. o ciągłości prawnej między II a III Rzecząpospolitą Polską (M.P. z 1998 r. Nr 12, poz. 200).

Ustawa Konstytucyjna z dnia 23 kwietnia 1935 r. (Dz.U. z 1935 r. Nr 30, poz. 227).

52 W.J. Wołpiuk, Naczelnik Państwa 1918-1922. Przedprezydencka forma władzy państwowej, „Przegląd Sejmowy” 2005, nr 5, s. 26.

53 Inną intrygującą poszlakę potwierdzającą istnienie retoryki ciągłości można odnaleźć w artykule H. Duszki-Jakimko, E. Kozerskiej, Civil society in Poland in the nineties of the twentieth century. Ideas and their reflection in the Constitution and in jurisprudence, „Studia nad Autorytaryzmem i Totalitaryzmem" 35, 2013, nr 1, s. 27-43. Autorki stawiają w nim tezę, że idea społeczeństwa obywatelskiego, pomimo licznych oficjalnych pozytywnych przywołań, nie znalazła faktycznego, pełnego odzwieciedlenia w orzecznictwie i w Konstytucji RP. 
Ustawa Konstytucyjna z dnia 19 lutego 1947 r. o ustroju i zakresie działania najwyższych organów Rzeczypospolitej Polskiej (Dz.U. z 1947 r. Nr 18, poz. 71).

Ustawa Konstytucyjna z dnia 22 lipca 1952 r. - Przepisy wprowadzające Konstytucję Polskiej Rzeczypospolitej Ludowej (Dz.U. z 1952 r. Nr 33, poz. 233).

Ustawa z dnia 17 marca 1921 r. - Konstytucja Rzeczypospolitej Polskiej (Dz.U. z 1921 r. Nr 44, poz. 267).

Ustawa z dnia 13 lipca 1957 r. o obrocie nieruchomościami rolnymi (Dz.U. z 1957 r. Nr 39, poz. 172 ze zm.).

Ustawa z dnia 17 maja 1990 r. o podziale zadań i kompetencji określonych w ustawach szczególnych pomiędzy organy gminy a organy administracji rządowej oraz zmianie niektórych ustaw (Dz.U. z 1990 r. Nr 34, poz. 198).

Ustawa z dnia 27 września 1990 r. o wyborze Prezydenta Rzeczypospolitej Polskiej (Dz.U. z 1990 r. Nr 67, poz. 398; Dz.U. z 1990 r. Nr 79, poz. 465).

Ustawa z dnia 21 sierpnia 1997 r. o gospodarce nieruchomościami (tekst jedn. Dz.U. z 2000 r. Nr 46, poz. $543 \mathrm{ze}$ zm.).

Zaproszenie do Warszawy Prezydenta Rzeczypospolitej Ryszard Kaczorowskiego dla przekazania insygniów i urzędu prezydenckiego na Zamku Królewskim w Warszawie w dniu 22 grudnia 1990 r. (Dz.U. z 1990 r. Nr 5, dział nieurzędowy).

\section{Artykuły i monografie}

Ash T.G., Wiosna obywateli. Rewolucja 1989 widziana w Warszawie, Budapeszcie, Berlinie i Pradze, Londyn 1990.

Berezowski M., Koniec epoki. Wywiady, Warszawa 1991.

Cenckiewicz S., Dlugie ramię Moskwy. Wywiad wojskowy Polski Ludowej 1943-1991 (wprowadzenie do syntezy), Warszawa 2011.

Cenckiewicz S., Oczami bezpieki. Szkice i materiały z dziejów aparatu bezpieczeństwa PRL, Warszawa 2004.

Codogni P., Okrągly Stót, czyli polski Rubikon, Warszawa 2009.

Czeszejko-Sochacki Z., Projekt nowej konstytucji (przeglą zagadnień węzłowych), „Państwo i Prawo" 1991, nr 7.

Dembiński L., Uwagi o ustroju III Rzeczpospolitej, „Tygodnik Powszechny” 1990, nr 28.

Domarańczyk Z., 100 dni Mazowieckiego, Warszawa 1990.

Dubiński K., Magdalenka. Transakcja epoki. Notatki z poufnych spotkań Kiszczak-Watęsa, Warszawa 1990.

Dudek A., Historia polityczna Polski 1989-2005, Kraków 2007.

Dudek A., Reglamentowana rewolucja. Rozkład dyktatury komunistycznej w Polsce 1988-1990, Kraków 2014.

Dudek A., Ślady PeeReLu: ludzie, wydarzenia, mechanizmy, Kraków 2005.

Działocha K., Państwo prawne $w$ warunkach zmian zasadniczych systemu prawa RP, „Państwo i Prawo" 1992, nr 1.

Gebert K., Mebel, Londyn 1990.

Geremek B., Żakowski J., Rok 1989. Bronisław Geremek odpowiada, Jacek Żakowski pyta, Warszawa 1990.

Kallas M., Lityński A., Historia ustroju i prawa Polski Ludowej, Warszawa 2003.

Kowalski S., Narodziny III Rzeczypospolitej, Warszawa 1996.

Kto jest kim - Okragły stót. Solidarność, opozycja. Biogramy, wypowiedzi, red. W. Adamiecki et al., Warszawa 1989.

Kubiak A., Państwo prawne - idea, postulaty, dylematy, „Państwo i Prawo” 1991, nr 7. 
Kulig A., Dwie prowizoryczne Konstytucje lutowe z 1919 r.: polska i niemiecka, [w:] Ustroje historia $i$ współczesność. Polska - Europa - Ameryka Łacińska. Księga jubileuszowa dedykowana Profesorowi Jackowi Czajowskiemu, red. M. Grzybowski, G. Kuca, P. Mikuli, Kraków 2013. Leski K., Coś, czyli rzecz o okraglym stole, Warszawa 1989.

Łętowska E., Wystapienie Rzecznika Praw Obywatelskich w Sejmie, „Państwo i Prawo” 1990, nr 5. Małkiewicz A., Wybory czerwcowe 1989, Warszawa 1994.

Mentzel Z., Pod kreską. Ostatnie kwartały PRL, Warszawa-Londyn 1990.

Okrągly Stót, oprac. K. Dubiński, Warszawa 1999.

Okragty stót, oprac. J. Barszczewski et al., cz. 1 i 2, Warszawa 1989.

Okrągly stót. Dokumenty i materiały, wyb. B. Brzostek et al., t. 1-5, Szczecin-Warszawa 2004.

Olszewski J., Państwo przede wszystkim, „Rzeczpospolita” 1991, nr 153.

Paczkowski A., Polska 1986-1989. Od kooptacji do negocjacji. Kilka uwag o wchodzeniu w proces zmiany systemowej, Warszawa 1997.

Partie i koalicje partyjne III Rzeczypospolitej, red. K.A. Paszkiewicz, Wrocław 2004.

Pernal M., Skórzyński J., Gdy niemożliwe stało się możliwe. Kalendarium Solidarności 1980-1989, Warszawa 2005.

Polska 1986-1989: koniec systemu. Materiały międzynarodowej konferencji: Miedzeszyn, 21-23 października 1999, red. P. Machcewicz et al., t. 1-3, Warszawa 2002.

Polska, wybory '89, wyb. i układ R. Kałuża, Warszawa 1989.

Porozumienia okragłego stołu, [w:] Konstytucje Polskie 1918-1998, oprac. T. Mołdawa, Warszawa 1999.

Pospieszalski K.M., Ziembiński Z., Konstytucja rocznicowa czy konstytucja wiekopomna?, „Ruch Prawniczy, Ekonomiczny i Socjologiczny" 1991, z. 1.

Raina P., Droga do „, Okraglego Stotu”. Zakulisowe rozmowy przygotowawcze, Warszawa 1999.

Reale G., Historia filozofii starożytnej, t. 1. Od początków do Sokratesa, Lublin 1994.

Rok 1989. Nowa Polska, odmieniona Europa, red. A. Kojder, Warszawa 1999.

Roszkowski W., Najnowsza historia Polski 1989-2011, Warszawa 2011.

Scheffler T., Prawne aspekty wprowadzenia stanu wojennego $w$ Polsce $w$ dniu 13 grudnia 1981 r., [w:] Idee jako źródło instytucji politycznych i prawnych, red. L. Dubel, Lublin 2003.

Scheffler T., Przestepstwo publicznego propagowania faszystowskiego lub innego totalitarnego ustroju państwa (art. 256 k.k.). Analiza doktrynologiczna wybranych wypowiedzi piśmiennictwa i judykatury. Część ogólna, „Studia nad Autorytaryzmem i Totalitaryzmem”34, 2012, nr 3.

Skórzyński J., Od Solidarności do wolności, Warszawa 2005.

Skórzyński J., Ugoda i rewolucja. Władza i opozycja 1985-1989, Warszawa 1995.

Smolak M., Wykładnia prawa a zmiana społeczno-polityczna, [w:] Studia z filozofii prawa, red. J. Stelmach, Kraków 2001.

Smoleński P., Szermierze okrąłego stotu. Zwątpienia i nadzieje, Paryż-Warszawa 1989.

Sokolewicz W., Kwietniowa zmiana konstytucji, „Państwo i Prawo” 1989, nr 6.

Sokolewicz W., Rzeczpospolita Polska - demokratyczne państwo prawne (uwagi na tle ustawy z 29 XII 1989 o zmianie Konstytucji), „Państwo i Prawo” 1990, nr 4.

Sójka J., O koncepcji form symbolicznych Ernsta Cassirera, Warszawa 1988.

Strzembosz A., Rzeczpospolita Polska państwem prawnym - czy naprawdę?, „Rzeczpospolita” 1991, nr 234.

Szacki J., Marzenia i rzeczywistość polskiej demokracji, „Res Publica” 1991, nr 5.

Tajne dokumenty Biura Politycznego i Sekretariatu KC. Ostatni rok władzy 1988-1989, oprac. S. Perzkowski [Andrzej Paczkowski], Londyn 1994.

W poszukiwaniu nowego sensu prawa. Wywiad z prof. T. Zielińskim, „Rzeczpospolita” 1991, nr 157. Wasilewski A., Aktualizacja porządku prawnego — potrzeby i rygory, „Państwo i Prawo” 1992, nr 5. Wołpiuk W.J., Naczelnik Państwa 1918-1922. Przedprezydencka forma władzy państwowej, „Przegląd Sejmowy” 2005, nr 5.

Studia nad Autorytaryzmem i Totalitaryzmem 39, nr 2, 2017

(C) for this edition by CNS 
Wróblewski J., Z zagadnień pojęcia i ideologii demokratycznego państwa prawnego (analiza teoretyczna), „Państwo i Prawo” 1990, nr 6.

Wyrzykowski M., Legislacja - demokratyczne państwo prawa, radykalne reformy polityczne i gospodarcze, „Państwo i Prawo” 1991, nr 5.

Zakrzewska J., Nowa Konstytucja Rzeczpospolitej, „Państwo i Prawo” 1990, nr 4.

Zawadzki S., Nowa konstytucyjna definicja polskiej państwowości, „Państwo i Prawo” 1990, nr 5.

Ziembiński Z., „Lex” a „,ius” w okresie przemian, „Państwo i Prawo” 1991, nr 6.

\section{THE RHETORIC OF CONTINUITY: ON THE JURIDICAL LEGACY \\ OF THE SECOND POLISH REPUBLIC \\ AND COMMUNIST GOVERNMENTS}

\section{Summary}

The aim of the article is to establish whether the continuity between the Second and Third Polish Republics officially declared by the Polish elites is based on facts. The authors analyse the question with regard to three areas: symbolic events (handing over of the presidential insignia in 1990 and the 1998 resolution of the Senate of the Republic of Poland on legal continuity), judgements of ordinary courts and the Constitutional Court as well as legal scholarship. In their conclusion they point out that the rhetoric of continuity between the Second and the Third Polish Republics on the legal level hides real continuity between the communist regime and the normative system in force in Poland since 1989.

Keywords: law, totalitarianism, continuity, change, rule of law, symbolic forms.

Ewa Kozerska

ekozerska@uni.opole.pl

Tomasz Scheffler

tomasz.scheffler@uwr.edu.pl 